\title{
Magnetotactic Bacteria and Magnetosomes: Basic Properties and Applications
}

\author{
Kamil G. Gareev ${ }^{1, *(\mathbb{D}}$, Denis S. Grouzdev ${ }^{2} \mathbb{D}$, Petr V. Kharitonskii ${ }^{3}$, Andrei Kosterov ${ }^{4} \mathbb{D}$, Veronika V. Koziaeva ${ }^{5}$, \\ Elena S. Sergienko ${ }^{4}$ and Maxim A. Shevtsov ${ }^{6,7}$ (D)
}

1 Department of Micro and Nanoelectronics, Saint Petersburg Electrotechnical University "LETI", 197376 Saint Petersburg, Russia

2 SciBear LLC, 13617 Tallinn, Estonia; denisgrouzdev@gmail.com

3 Department of Physics, Saint Petersburg Electrotechnical University “LETI”, 197376 Saint Petersburg, Russia; peterkh@yandex.ru

4 Department of Earth Physics, Saint Petersburg University, 199034 Saint Petersburg, Russia; a.kosterov@spbu.ru (A.K.); e.sergienko@spbu.ru (E.S.S.)

5 Research Center of Biotechnology of the Russian Academy of Sciences, Institute of Bioengineering, 119071 Moscow, Russia; vkoziaieva@mail.ru

6 Laboratory of Biomedical Nanotechnologies, Institute of Cytology of the Russian Academy of Sciences (RAS), 194064 Saint Petersburg, Russia; shevtsov-max@mail.ru

7 Laboratory of Translational Oncology, Research Centre for Personalized Medicine, Almazov National Medical Research Centre, 197341 Saint Petersburg, Russia

* Correspondence: kggareev@etu.ru

check for updates

Citation: Gareev, K.G.; Grouzdev, D.S.; Kharitonskii, P.V.; Kosterov, A.; Koziaeva, V.V.; Sergienko, E.S.;

Shevtsov, M.A. Magnetotactic Bacteria and Magnetosomes: Basic Properties and Applications. Magnetochemistry 2021, 7, 86. https:// doi.org/10.3390/magnetochemistry 7060086

Academic Editor: Alexios Douvalis

Received: 26 April 2021

Accepted: 15 June 2021

Published: 18 June 2021

Publisher's Note: MDPI stays neutral with regard to jurisdictional claims in published maps and institutional affiliations.

Copyright: (c) 2021 by the authors. Licensee MDPI, Basel, Switzerland. This article is an open access article distributed under the terms and conditions of the Creative Commons Attribution (CC BY) license (https:/ / creativecommons.org/licenses/by/ $4.0 /)$.

\begin{abstract}
Magnetotactic bacteria (MTB) belong to several phyla. This class of microorganisms exhibits the ability of magneto-aerotaxis. MTB synthesize biominerals in organelle-like structures called magnetosomes, which contain single-domain crystals of magnetite $\left(\mathrm{Fe}_{3} \mathrm{O}_{4}\right)$ or greigite $\left(\mathrm{Fe}_{3} \mathrm{~S}_{4}\right)$ characterized by a high degree of structural and compositional perfection. Magnetosomes from dead MTB could be preserved in sediments (called fossil magnetosomes or magnetofossils). Under certain conditions, magnetofossils are capable of retaining their remanence for millions of years. This accounts for the growing interest in MTB and magnetofossils in paleo- and rock magnetism and in a wider field of biogeoscience. At the same time, high biocompatibility of magnetosomes makes possible their potential use in biomedical applications, including magnetic resonance imaging, hyperthermia, magnetically guided drug delivery, and immunomagnetic analysis. In this review, we attempt to summarize the current state of the art in the field of MTB research and applications.
\end{abstract}

Keywords: magnetotactic bacteria; magnetosome; magnetite; magnetofossils; biomedicine; biotechnology; biogeoscience

\section{Introduction}

The formation of iron minerals due to biochemical processes has been known for several decades. Many organisms are able to synthesize various magnetic iron compounds such as magnetite (bacteria, protozoa, mollusks, arthropods, and chordate molds), ferrihydrite (bacteria, fungi, plants, animals), lepidocrocite (sponges, mollusks), goethite (bacteria, protozoa, annelids, mollusks), and some others [1,2]. Bacteria, in particular, are able to form intra- and extracellular grains of iron hydroxides, silicates, phosphates, sulfates and sulfides [3], and a wide range of nanosized particles of noble metals and semiconductor compounds [4].

The greatest interest, academic as well as including potential applications, is attracted by bacterial magnetite formed by a complex genetically mediated process [5-7] and localized in intracytoplasmic membrane vesicles-magnetosomes, responsible for magnetoreception of magnetotactic bacteria (MTB) [8]. These bacteria were first observed in samples of marine sediments, where they moved at a speed of about $100 \mu \mathrm{m} / \mathrm{s}$ [9] in 
a geomagnetic field having a strength of the order of $0.5 \mathrm{Oe}$, and the direction of movement was changed when the magnet polarity was reversed. Further studies revealed that MTB are widespread in marine, fresh, and extreme water environments of both hemispheres $[10,11]$. The optimal zone for MTB growth is usually the oxic-anoxic transition zone in the area of bottom sediments (Figure 1), and crystals of magnetite and greigite from dead bacteria make a significant contribution to remanent magnetization of sediments [12]. Fossil magnetosomes (magnetofossils) in most cases carry a reliable paleomagnetic signal in sedimentary rocks [13].

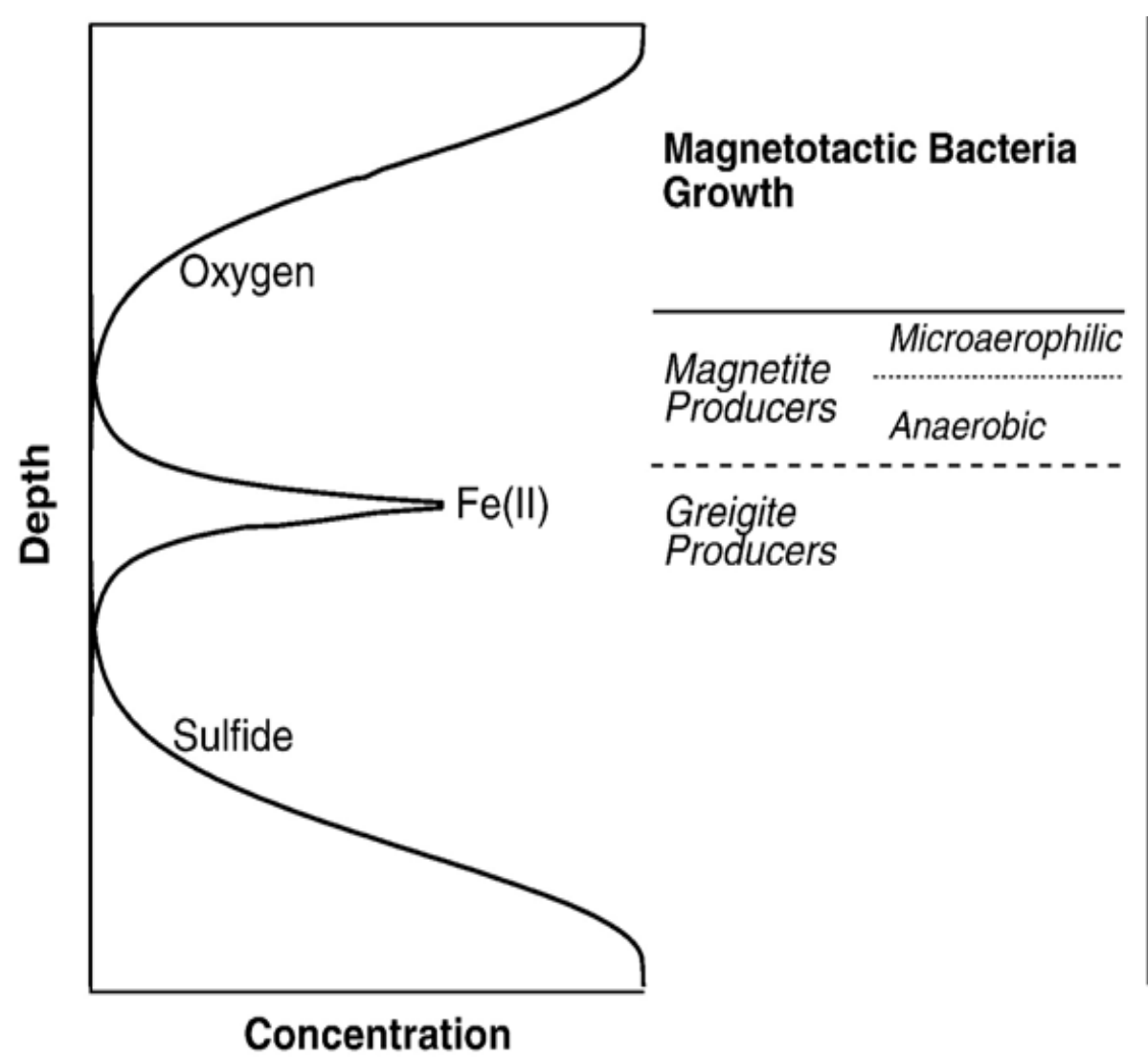

Magnetite Preservation

Maghemitization

Preservation of Unoxidized Magnetite.

Reductive Dissolution

Figure 1. Scheme of chemical gradients vs. typical depth optimal for the growth of various types of magnetotactic bacteria and magnetite transformations. Magnetite (greigite) crystals provide the bacteria with a net magnetic moment, which they employ for magnetotaxis, movement directed by the local magnetic field. Many magnetotactic bacteria grow preferentially under specific, narrow redox conditions. Redox gradients can exist on scales from millimeters to meters. Reprinted from [14], Earth-Science Reviews, Vol. 86, Kopp R.E., Kirschvink J.L., “The identification and biogeochemical interpretation of fossil magnetotactic bacteria", pp. 42-61, 2008, with permission from Elsevier.

Studies of the diversity of biomineralization and fossilization pathways of microorganisms in modern extreme conditions-such as hydrothermal springs, hypersaline and superalkaline lakes, sea-floor basalts, etc. - can help unravel the microbial activity of the early Earth [15]. The size and quantity of magnetite particles in MTB are relatively constant for a given bacterial species and, in most MTB, there are 10-30 particles per cell that constitute 50-100 $\mathrm{nm}$ along the long axis [16]. Morphologically, MTB are diverse including vibrions, rods, cocci, spirilla, and so-called "multicellular" organisms [17]. According to their present phylogenetic position, MTB are classified in the following phyla: Proteobacteria, Nitrospirota, Omnitrophota, Latescibacterota, Planctomycetota, Nitrospinota, Hydrogenedentota, Elusimicrobiota, Fibrobacterota, Riflebacteria, Bdellovibrionota, UBA10199, Desulfobacterota [18-21] (Figure 2). 


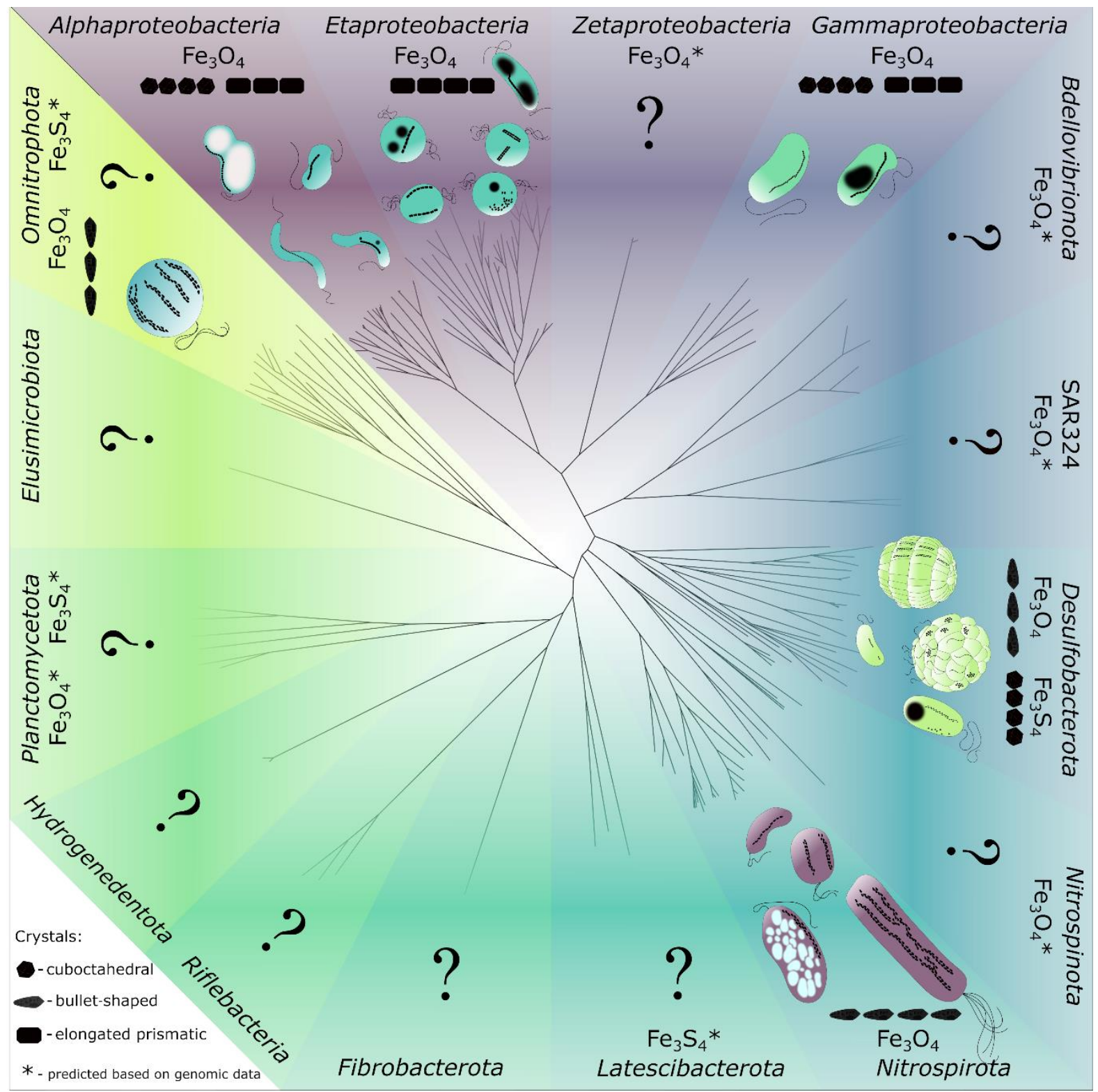

Figure 2. Phylogenetic distribution of MTB. The maximum likelihood phylogenomic tree was inferred from the concatenation of 120 single copy marker proteins using LG + F + I + G4 model. The analysis was performed on 264 genomes of cultured and uncultured MTB. Question marks indicate a lack of data on cell morphology and/or the shape and composition of magnetosome crystals.

Only a few MTB strains were isolated into a pure culture. Most of them belong to the genus Magnetospirillum [22]. MTBs observed in natural samples mostly remain uncultivated, and are studied by molecular biology and microscopic methods [11].

The biocompatibility of an iron biomineral sequestered within a phospholipid membrane is a promising feature for various biomedical and biotechnological applications related to magnetosomes and magnetosome-based complexes [23-26]. Possibilities of altering the chemical composition by substituting foreign metal for iron in magnetosome magnetite nanocrystals are investigated, the biomineralization process serving as a basis for developing new approaches to the synthesis of nanomaterials [27-30], such as e.g., biosynthesis of magnetite using human cells [31]. 


\section{MTB and Magnetosomes}

The nature of magneto-aerotaxis remains a subject of active research. According to some models, it reduces the search for conditions with low oxygen content to a onedimensional rather than three-dimensional problem, the latter usually associated with other mechanisms of cell taxis [32]. Using microcapillary analysis for 12 species of MTB, six variants of magneto-aerotaxis have been revealed [33]. Statistically significant changes in the cell shape of the Magnetospirillum magneticum strain occurred when the bacteria were exposed to a magnetic field, as compared with control conditions. However, in the Magnetospirillum gryphiswaldense strain, no morphological changes were observed under the same conditions, implying a difference in the arrangement of magnetosomes in two different strains. This emphasizes the importance of choosing the correct source strain of bacterial nanoparticles if a high sensitivity to external magnetic fields is required [34].

One of the most studied MTB are freshwater bacteria of the genus Magnetospirillum [35]. Magnetospirillum magneticum AMB-1 and Magnetospirillum gryphiswaldense MSR-1 are model microorganisms for studying the process of magnetosome biomineralization [36]. For these strains, metabolism and magnetosome formation have been studied under various growth conditions, which included, in particular, varying isotopic composition of iron [37]. For these two microorganisms, a longitudinal study of genetic determinants responsible for the magnetosome formation has been carried out and possible factors involved in the formation of the magnetosome membrane and biomineralization of magnetic crystals were elucidated $[7,38]$. Recently, it has been shown that MTB can form an additional pool of iron in the cytoplasm outside of magnetosomes [39], and that the process of magnetosome biomineralization requires maintaining the necessary redox conditions, regulating the content of intracellular reactive oxygen species to maintain the intracellular balance of ferric and ferrous iron $[40,41]$. This can contribute to the survival of MTB in the conditions of low oxygen content and high content of iron [42] and other transition metals [43].

Genomes of many MTB species were sequenced [20,21,44-60], and genes specific for magnetotactic bacteria were found, which control the magnetosome formation [61,62]. These genes are located in a so-called magnetosome genomic cluster (MGC) and are responsible for the formation of the magnetosome membrane, transport of iron into magnetosomes, nucleation and growth of magnetite crystals, and the shape and size of the latter [17,63-69]. Magnetite (greigite) crystals in magnetosomes can take the form of prism, cuboctahedron, bullet, or a combination of a cube and a dodecahedron, which is associated with the process of crystal growth [70] (Figure 3). Magnetosomes in MTB are commonly arranged in one or several parallel chains, although chaotically distributed magnetosomes have also been observed [49,52,71,72]. The mechanism of magnetosome formation [73,74] and their chains [75] in MTB has been investigated experimentally by electron cryotomography. The morphological characteristics of magnetite crystals obtained from some MTB are listed in Table 1. 

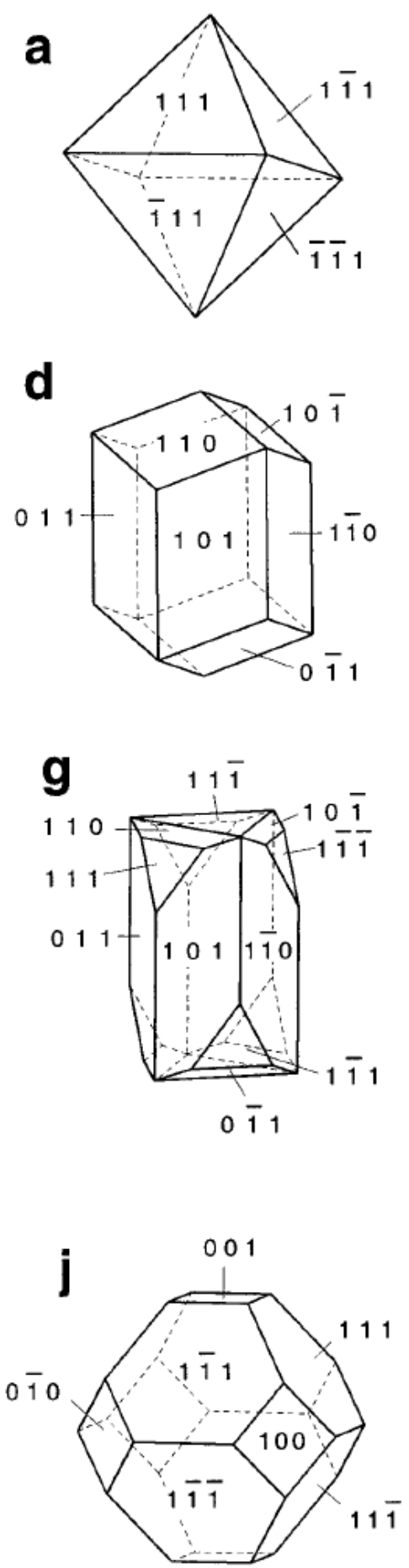
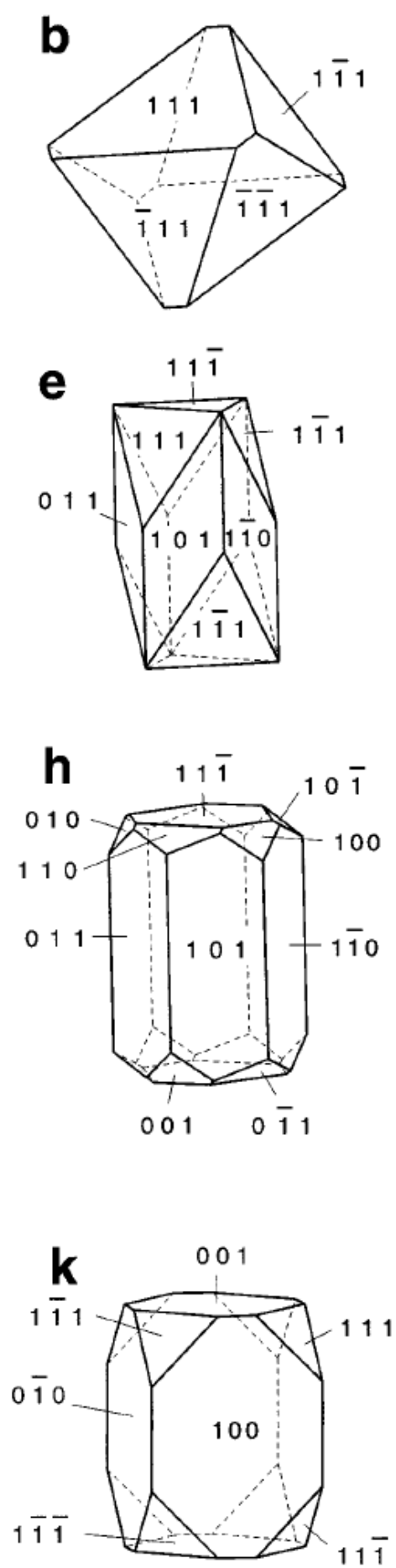
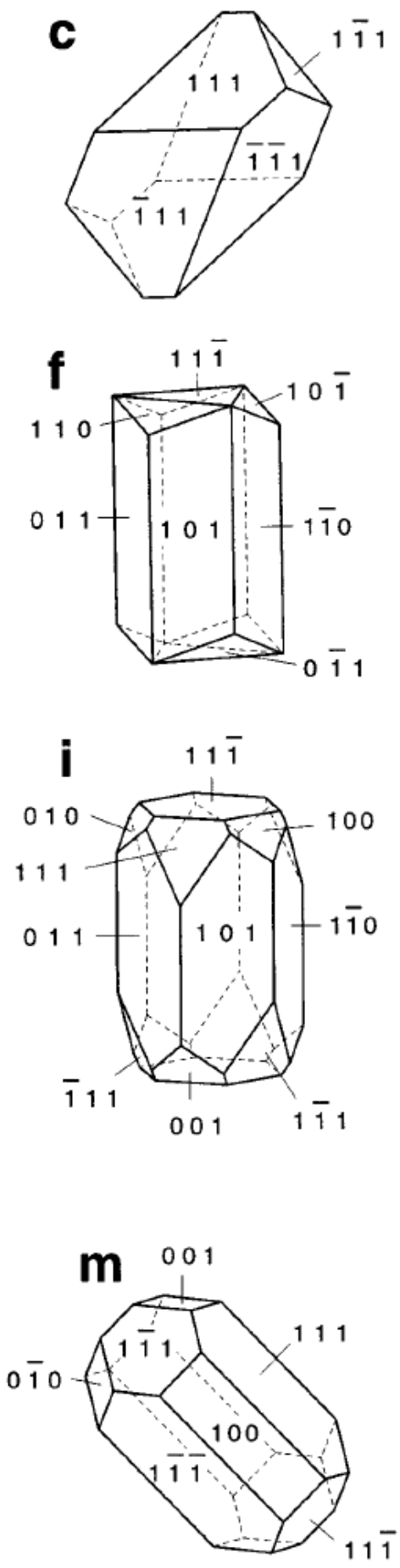

Figure 3. Shape combinations compatible with magnetite symmetry (Fd3m): (a) $\{111\}$ (octahedron); (b) distorted $\{111\}$; (c) elongated $\{111\} ;(\mathbf{d})$ elongated $\{110\} ;(\mathbf{e}-\mathbf{g})\{110\}+\{111\} ;(\mathbf{f})\{110\}+\{111\} ;(\mathbf{h}, \mathbf{i})\{110\}+\{111\}+\{100\} ;(\mathbf{j})\{100\}+\{111\}$ (cuboctahedron); $(\mathbf{k}, \mathbf{m})$ elongated $\{100\}+\{111\}$. The anisotropy of the environment could derive from an anisotropic flux of ions through the magnetosome membrane surrounding the crystal. The resulting crystals are distorted in a consistent species-specific manner. The cube $\{100\}$, octahedron $\{111\}$, and dodecahedron $\{110\}$ can, with certain distortions, create a wide range of shapes, taking into consideration those observed in magnetosomes. Reprinted from [70], American Mineralogist, Vol. 83, Devouard B., Pósfai M., Hua X., Bazylinski D.A., Frankel R.B., Buseck P.R., "Magnetite from magnetotactic bacteria: Size distributions and twinning", pp. 1387-1398. 1998. Copyright @ 1998, with permission from the authors and The Mineralogical Society of America. 
Table 1. Shape, size, and quantity of magnetosomes isolated from magnetotactic bacteria (MTB) of some species

\begin{tabular}{|c|c|c|c|c|c|}
\hline MTB Species & Crystal Shape & $\begin{array}{l}\text { Average Crystal } \\
\text { Length (nm) }\end{array}$ & $\begin{array}{l}\text { Average Crystal } \\
\text { Width (nm) }\end{array}$ & $\begin{array}{c}\text { Average } \\
\text { Magnetosomes } \\
\text { Quantity }\end{array}$ & Refs. \\
\hline $\begin{array}{l}\text { Magnetospirillum } \\
\text { magneticum AMB-1 }\end{array}$ & $\begin{array}{c}\text { prismatic, } \\
\text { cuboctahedral }\end{array}$ & \multicolumn{2}{|c|}{$30-50$} & $15-20$ & {$[32,35,73,75-78]$} \\
\hline Magnetococcales spp. & $\begin{array}{c}\text { prismatic, } \\
\text { cuboctahedral }\end{array}$ & $70-250$ & $40-200$ & 10-200 & {$[49,52,72,79-81]$} \\
\hline $\begin{array}{c}\text { Magnetovibrio blakemorei } \\
\text { MV-1 }\end{array}$ & prismatic & $50-60$ & $35-40$ & $2-20$ & {$[74,82]$} \\
\hline $\begin{array}{c}\text { Magnetospirillum } \\
\text { gryphiswaldense MSR-1 }\end{array}$ & cuboctahedral & \multicolumn{2}{|c|}{$30-50$} & $15-40$ & {$[43,63,68,83-85]$} \\
\hline $\begin{array}{c}\text { Desulfovibrio magneticus } \\
\text { RS-1 }\end{array}$ & bullet-shaped & $40-70$ & $20-40$ & $<10$ & [86] \\
\hline $\begin{array}{c}\text { Nitrospirota bacterium } \\
\text { MYR-1 }\end{array}$ & bullet-shaped & $40-45$ & 80-180 & \multirow{2}{*}{ up to 1000} & [87] \\
\hline $\begin{array}{l}\text { Ca. Magnetobacterium } \\
\text { bavaricum TM-1 }\end{array}$ & bullet-shaped & $35-40$ & $100-120$ & & {$[88,89]$} \\
\hline
\end{tabular}

The interaction of proteins associated with magnetosome formation has been an important research subject in recent years [90]. The structure of some of these proteins is well understood [91]; however, the role of individual magnetosome proteins in each stage of the biomineralization process has not been established. Many studies are carried out by directed modification using plasmid vectors [92] to obtain mutant MTB strains, including non-magnetic ones $[36,84,93]$. A promising direction in MTB bioengineering is inducing biomineralization in initially non-magnetotactic bacteria [94,95], and obtaining mutant strains with a genetically modified membrane [96]. Another one is the possibility of synthesizing biomimetic magnetic particles with faceted magnetite crystals with a narrow size distribution by using a combination of magnetosome proteins MamC and Mms6 $[97,98]$.

The process of obtaining a pure MTB culture is very complicated [99] and industrial cultivation of even the most studied species-e.g., Magnetospirillum magnetotacticum-requires the use of large-volume fermenters, reaching 30 [100] and even $50 \mathrm{~L}$ [101] (Figure 4). In addition, constant precise control of the dissolved iron content in the nutrient medium and its $\mathrm{pH}$ [102], and maintaining oxygen concentration in the gas phase $<5 \%$ are required [76]. However, recently, a new approach to accelerated production of MTB biomass using fermentation has been proposed, which does not require precise control of the gas environment [103]. Also, a method for controlling the MTB physiology has been developed based on the use of the flow cytometry, so that the process of growing MTB can be significantly simplified [104]. 


\begin{tabular}{|c|c|c|}
\hline 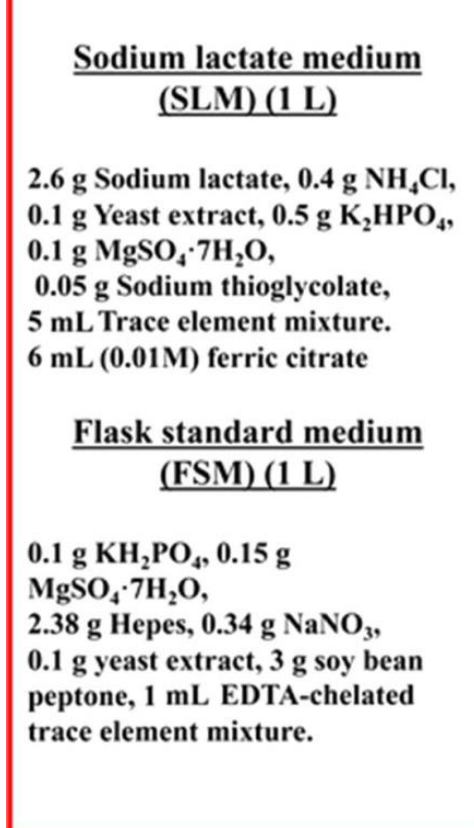 & $\begin{array}{l}\text { Factors affecting magnetosome formation } \\
\text { Dissolved oxygen; Carbon source; Nitrogen source } \\
\text { Iron source; Sulfur source; } \mathrm{pH} \& \text { Temp } \\
\text { Redox potential ; Salt concentration }\end{array}$ & 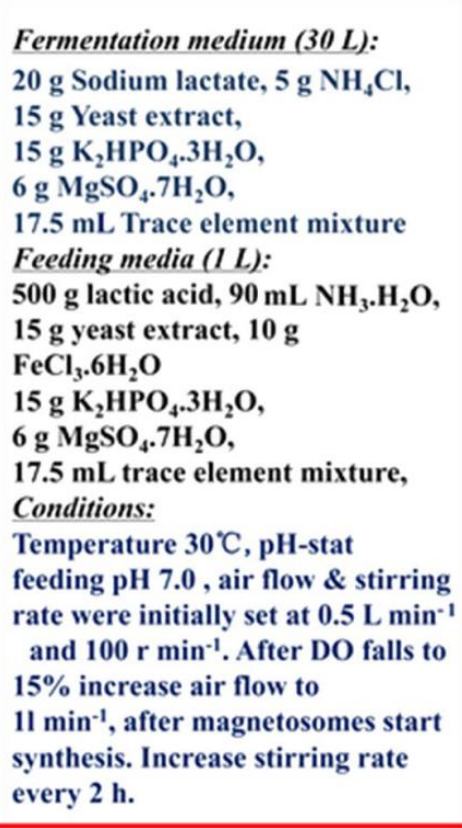 \\
\hline
\end{tabular}

Figure 4. Culture media used for cultivation of Magnetospirillum gryphiswaldense MSR-1 strain and factors influencing the growth of MSR-1. Optimal culture conditions (in regard to dissolved oxygen concentration, $\mathrm{pH}$, nutrient composition, and salt concentrations) are highly restrictive. A variety of control strategies have been evaluated for achieving more efficient magnetosome yield. Optimized culture conditions are shown for growth of MSR-1. Reprinted from [100], Basit, A., Wang, J., Guo, F. et al. Improved methods for mass production of magnetosomes and applications: a review. Microb Cell Fact 19, 197 (2020), license CC BY 4.0.

\section{Physicochemical Properties and Isolation of Magnetosomes}

The magnetic properties of MTB and isolated magnetosomes correspond to magnetostatically interacting magnetite crystals and are described using the model of a chain of spheres [105]. The magnetic characteristics of magnetosomes (saturation magnetic moment at $T=300 \mathrm{~K} \mathrm{M}_{\mathrm{s} 300 \mathrm{~K}}$, remanent coercivity at $T=300 \mathrm{~K} \mathrm{H}_{c r 300 \mathrm{~K}}$, remanence to saturation magnetization ratio at $T=300 \mathrm{~K} M_{r s} / M_{s 300 K}$ and Verwey transition temperature $T_{V}$ [82]) isolated from various MTBs are listed in Table 2.

Table 2. Magnetic characteristics of magnetosomes isolated from MTB of some species

\begin{tabular}{|c|c|c|c|c|c|}
\hline MTB Species & $M_{s 300 \mathrm{~K}}, 10^{-3} \mathrm{emu}^{1}$ & $H_{c r 300 \mathrm{~K}}, \mathrm{Oe}^{2}$ & $M_{r s} / M_{s 300 \mathrm{~K}}{ }^{3}$ & $T_{V}, K^{4}$ & Refs. \\
\hline $\begin{array}{c}\text { Magnetospirillum } \\
\text { magnetotacticum AMB-1 }\end{array}$ & $1.6-4.5$ & $128-380$ & $0.43-0.50$ & \multirow{2}{*}{$100-118$} & {$[39,77,106-111]$} \\
\hline $\begin{array}{c}\text { Magnetospirillum } \\
\text { gryphiswaldense MSR-1 }\end{array}$ & $0.2-1.5$ & $96-234$ & $0.38-0.50$ & & {$[68,85,112-117]$} \\
\hline $\begin{array}{c}\text { Magnetovibrio blakemorei } \\
\text { MV-1 }\end{array}$ & 3.0 & $250-350$ & $0.46-0.50$ & $100-117$ & {$[82,118]$} \\
\hline $\begin{array}{c}\text { Ca. Magnetobacterium } \\
\text { bavaricum TM-1 }\end{array}$ & $1.5-8.0$ & $400-460$ & $0.32-0.51$ & $100-110$ & {$[88,89]$} \\
\hline $\begin{array}{c}\text { Magnetococcus marinus } \\
\text { MC-1 }\end{array}$ & - & - & - & 102 & [118] \\
\hline
\end{tabular}

${ }^{1}$ Saturation magnetic moment at $T=300 \mathrm{~K} .{ }^{2}$ Remanent coercivity at $T=300 \mathrm{~K} .{ }^{3}$ Remanence to saturation magnetization ratio at $T=300 \mathrm{~K}$.

${ }^{4}$ Verwey transition temperature.

Even for crystals about $30 \mathrm{~nm}$ in size, magnetostatic interaction of grains arranged in chains leads to their magnetic moments being in blocked state in a zero external magnetic field $[108,119]$. Experiments and numerical modeling have revealed that the organization 
of magnetosomes into chains plays a significant role in the process of their maturation, while the effect of chains is small in the process of MTB cell division [120]. Changes in the iron oxidation state and size distribution of magnetosome crystals vs. time have been studied at early stages of the biomineralization process [121]. Growing MTBs in a magnetic field, weakened compared to the geomagnetic field, can affect the size of magnetosome crystals and the expression of some MGC genes [122].

Various electron microscopy techniques, particularly the one using the signal from inelastically scattered electrons, have been applied to study MTB ultrastructure. Examples include observing the shape of magnetosomes and their chains without isolating them from bacterial cells [123], and directly obtaining images of individual magnetosome membranes [124]. Use of energy dispersive $\mathrm{X}$-ray analysis allows mapping the distribution of chemical elements and the energies of chemical bonds within MTB [109,125]. New modifications of transmission electron microscopy using a graphene liquid cell with an encapsulated $1 \mu \mathrm{L}$ MTB sample allow direct observation of the biomineralization process in high resolution [126].

Images of magnetosome chains, similarly to chain aggregates of synthetic magnetic particles [127], have been also obtained by atomic force [128,129], magnetic force [130,131], and scanning transmission X-ray [125] microscopy. During the formation of chain structures and changes in rheological properties in a suspension, isolated magnetosomes appear quite similar to synthetic magnetic particles [132,133]. Mathematical models have been constructed that describe the mechanical properties of chains of magnetosomes taking into consideration the effect of the filament connecting them in MTBs [134], and energy parameters of magnetosome magnetostatic interaction in a chain [135]. Immobilization of MTB in a gel matrix made of hydrated silica affects the reaction of magnetosome chains to changes in the direction of an external magnetic field and leads to a reversal of chains and disruption of their structure [109]. However, for freeze dried immobilized MTB, application of magnetic fields up to $1 \mathrm{~T}$ does not lead to the destruction of chains [85].

According to high-resolution transmission electron microscopy [87], faceting of magnetosome crystals by planes with high Miller indices [136] is apparently determined by a multistage biomineralization process, controlled by anions and organic molecules inside a vesicle and other intra- [80] and extracellular [137] factors, and may differ for magnetosomes within the same chain [81]. Formation of $\varepsilon-\mathrm{Fe}_{2} \mathrm{O}_{3}$ at an intermediate stage of biomineralization in magnetosomes has been hypothesized [138]. This metastable polymorph of iron (III) oxide exists in a narrow crystal size range and, with an increase in the latter, transforms to $\alpha-\mathrm{Fe}_{2} \mathrm{O}_{3}$ [5]. Adding inorganic manganese [139] or cobalt [111] salts directly to the MTB nutrient medium allows obtaining metal-substituted magnetite crystals with modified shape, size, and magnetic properties.

Isolating magnetosomes from MTB starts with exposure to air, followed by ultrasonic cell lysis or using of a laboratory extrusion cell disintegrator (French press) [140-142], stirring in a shaker, magnetic separation of magnetosomes, or separation by centrifugation with removing cellular debris and multiple rinsing with buffered solutions and deionized water $[100,131,143]$. An automated MTB cultivation mode with variable oxygen content can be used to control the particle size and, correspondingly, the magnetic characteristics of magnetite in order to adapt them for the desired application [144]. The mass of dry particles obtained from MTB is small and does not exceed $20 \mu \mathrm{g}$ per $1 \mathrm{mg}$ of lyophilized biomass [145]. The maximum achieved productivity is about $150 \mathrm{mg}$ of dry biomass per 1 L of culture per day [146].

\section{Magnetofossils and Their Properties}

Studies of marine clays from the western part of Crete [147] and the Pacific Ocean [148], deep-sea sediments from the Atlantic [149] and Pacific [150,151] oceans and the Black Sea [152], microbial mats [153] and sapropels of the Baltic Sea [154], stromatolites in coastal waters [155], sediments from freshwater lakes and rivers of central Russia [156], stratified ferruginous lakes [57] and a Cisalpine lake [157] have shown that single-domain mag- 
netite or greigite from MTB is a major carrier of stable remanent magnetization in these rocks. Methods used for the analysis included thermal and alternating field demagnetization of natural remanent magnetization, measurement of hysteresis loops, and curves of isothermal saturation remanent magnetization and anhysteretic remanent magnetization. More advanced methods such as construction of first order reversal curve (FORC) diagrams [77,158] and ferromagnetic resonance spectroscopy (FMR) [159] have been applied to selected samples.

Chemical stability of submicron magnetite particles in marine sediments is due to slightly alkaline conditions and may differ in the case of freshwater reservoirs [157]. Relative proportion of maghemite formed as a result of magnetite oxidation can vary from 0 (in the initial magnetosomes) to $100 \%$, depending on the geography of the sediments [79]. Increased oxygen content in freshwater lake sediments leads to a greater tolerance to oxygen in MTB; the magnetosomes they form commonly have lower coercive force [160]. Environmental conditions also affect the shape of magnetite crystals in magnetofossils, isotropic crystals dominating in an oxic medium, and anisotropic crystals in a reducing one [161]. The relationship between magnetofossil properties and the alternation of glacial cycles has been observed, probably mediated by changes in the oxygen level in pore water [14] and other global climatic changes [162].

Extraction of submicron particles of biogenic magnetite from sediments includes the separation of non-magnetic phases and separation of chains formed in MTB, and takes no more than 30-60 min [163]. TEM images of individual magnetofossil crystals show the high degree of structural perfection, which, however, can be destroyed over time due to the dissolution of magnetite in the pore space electrolyte [164]. Oxidation of magnetite to maghemite in magnetosomes when exposed to temperatures above their stability threshold (approximately $300{ }^{\circ} \mathrm{C}$ [143]) manifests itself in pronounced nonstoichiometry, resulting in a decrease of the Verwey transition temperature and ultimately in the disappearance of the transition [112]. Alongside the formation of magnetosome chains [106], effect of magnetite nonstoichiometry can be detected using FMR spectroscopy [113]. This method can be further used to determine the content of magnetofossils in a sample, since the effective g-factor, characterizing the ratio of the magnetic and angular momenta of a particle, and the resonance curve width of synthetic magnetite particles differ significantly from the corresponding characteristics of particles biomineralized by various bacteria $[107,115,164,165]$. Fields of uniaxial and cubic magnetic anisotropy of crystals of various shapes $[86,114,166]$ have been determined by FMR spectroscopy, electron cryotomography, and measurement of dynamic hysteresis loops. FMR curve parameters of magnetofossils have been found to change along the length of sediment cores, thus yielding paleoclimatic information [167].

The method of magnetic granulometry [168,169], along with other approaches in rock magnetism $[88,89,116,165]$, confirms that the shape and size of bacterial magnetite crystals correspond to a single-domain [170] or pseudo-single-domain [82] (metastable singledomain [167]) state, with the aspect ratio and particle length varying over a wide range, up to one order of magnitude, depending on magnetofossil geography [171], and differs little for cultivated and non-cultivated MTB strains when taking into consideration statistical data [172]. Exceptionally, multi-domain [173] and superparamagnetic [117] magnetite grains originating from magnetofossils have been found in natural conditions. Biogenic single-domain crystals of greigite [174] close in size to magnetite crystals differ from the latter by a 2-3 times lower coercive force [175]. Figure 5 illustrates size range of stable single domain (SSD) bacterial magnetite crystals. The most commonly studied Magnetospirillum genus MTB produce almost cubic particles about 40-60 nm lying squarely in the SSD region. Therefore, fossilized MTB retain stable magnetization and are an important carrier of paleomagnetic signal in sediments. 


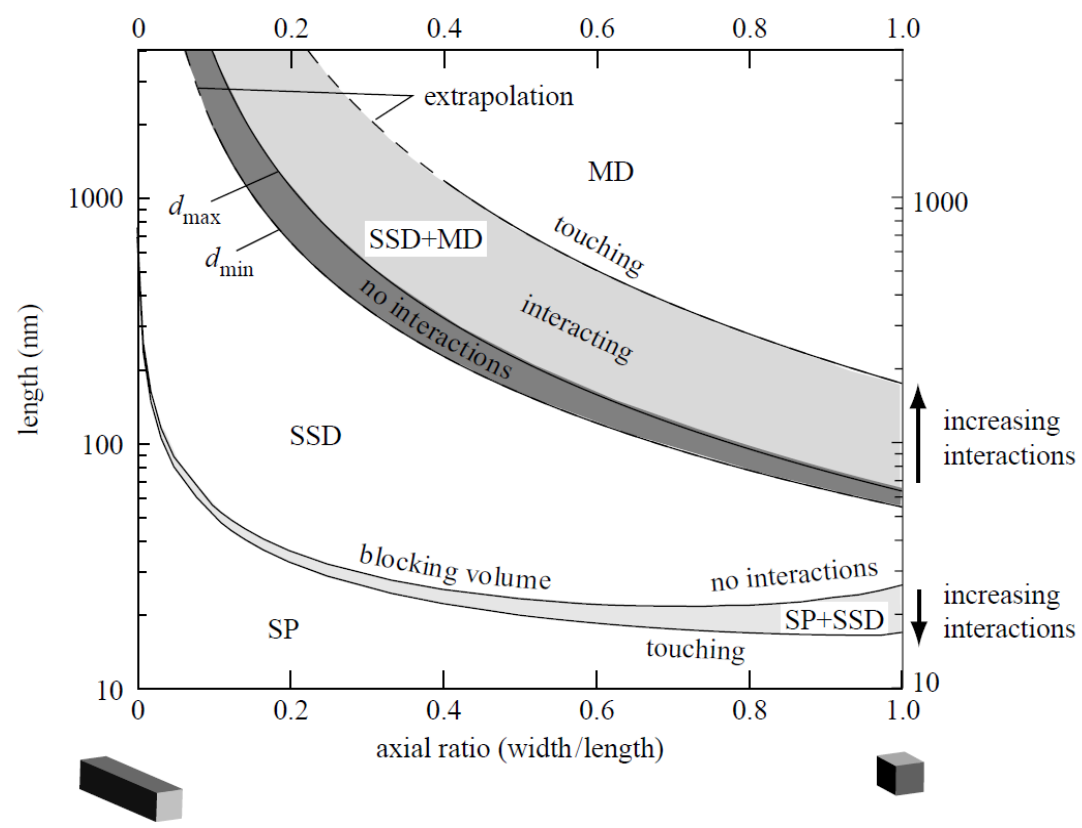

Figure 5. Diagram of magnetic states of magnetite; the regions of a stable single-domain (SSD) state are indicated for individual grains and for chains with and without taking into consideration Table 60. s below which all grains are considered to be in a superparamagnetic (SP) state where the direction of a magnetic moment of an individual grain is constantly changed by thermal agitation. For non-interacting grains, there is a range of grain sizes marked by $d_{\min }$ and $d_{\max }$, where both SSD and multi-domain (MD) states are possible. Changes in both grain shape and volume contribute to the location of critical boundaries. Reprinted from [119], J. R. Soc. Interface, Vol. 6, Muxworthy A.R., Williams W., “Critical superparamagnetic/single-domain grain sizes in interacting magnetite particles: implications for magnetosome crystals", pp. 1207-1212. 2009. Copyright (C 2009, with permission from the authors and The Royal Society (U.K.).

\section{Application of Magnetosomes in Biomedicine and Biotechnology}

High biocompatibility of bacterial magnetosomes is confirmed by studies of cytotoxicity (MTT test), hemolytic activity and genotoxicity [176,177], and influences a range of potential applications in biomedicine [178,179], including oncology [180] (Figure 6).

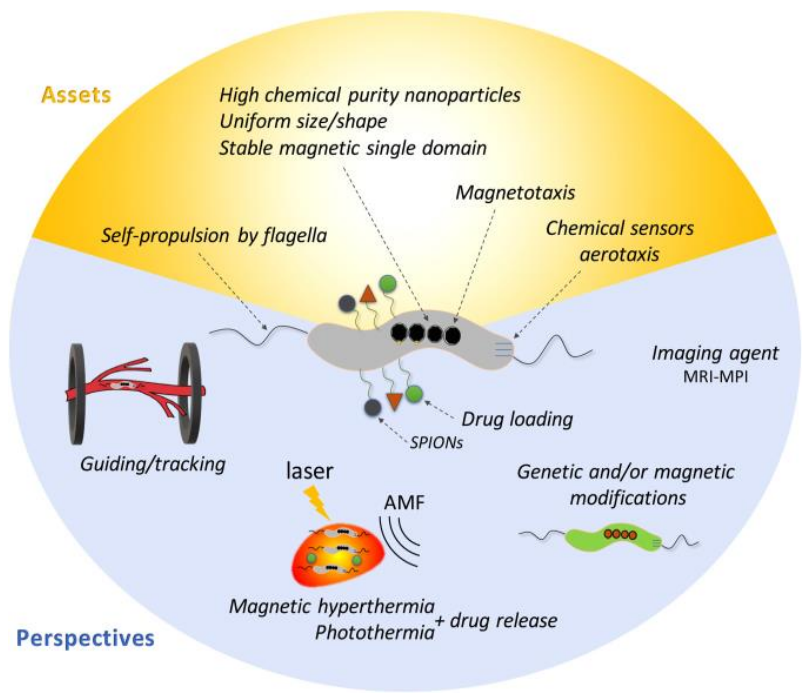

Figure 6. Schematic representation of the biological features of MTB, which determines the prospects for their use as theranostics agents in oncology. At present, only the fundamental properties of MTB 
suitable for the biomedical applications, including self-propulsion, magnetotaxis and aerotaxis, are reasonably well studied. At the same time, other possible biomedical applications of MTB include magnetically guided drug delivery, alternate magnetic field (AMF) hyperthermia, magnetic resonance imaging (MRI) or magnetic particle imaging (MPI) and modification of MTB membrane with drugs or superparamagnetic iron oxide-based nanoparticles (SPIONs). Reprinted from [181], J. Appl. Phys., Vol. 128, Fdez-Gubieda M.L., Alonso J., García-Prieto A., García-Arribas A., Fernández Barquín L., Muela A., "Magnetotactic bacteria for cancer therapy", Article 070902. 2020. Copyright (C 2020, with permission from the authors and AIP Publishing.

The possibility of using magnetosomes from magnetotactic cocci [182] and spirilla [183] as contrast agents has been established experimentally, which, in combination with effective control by means of an external magnetic field, can be used for magnetic resonance imaging (MRI) in the positive and negative contrast mode, including that in real time [181]. MRI can be used to create bacterial or hybrid medical nanorobots that can controllably move through the human circulatory system [184,185], as demonstrated in a model system based on a microfluidic chip [186]. When functionalized through genetic modification, magnetosomes may also become tissue-specific, highly sensitive molecular probes for MRI due to their high transverse relaxivities, up to $600 \mathrm{mM}^{-1} \mathrm{~s}^{-1}$ and tropism to tumor tissue $[187,188]$. Reporter gene expression using magnetosome genes to create endogenous MRI contrast for longitudinal molecular imaging was described [189].

Magnetosomes with an artificially modified membrane are able to selectively bind to monoclonal antibodies [129] and can be used for magnetic separation of cells [190], conducting automated magnetic immunological analysis by immuno-PCR [191], creating new electrochemical sensors for detecting pathogenic bacteria and their secreted toxins [192], and immunomagnetic analysis for anthropogenic pollutants [193]. Modification of magnetosome membranes with aminosilane allows using these for isolation of nucleic acids in PCR diagnostics of whole blood [194], or of bacterial cell culture [195] samples (Figure 7).

A comparative study of the immobilization of enzymes (oxidase and uricase) on the surface of biogenic magnetic particles and particles of synthetic magnetite has shown 30-80 times greater efficiency and an approximately 30-fold increase in enzyme activity in biogenic particles [145]. Genetic engineering of magnetosomes can provide high catalytic activity for a wide range of enzymes, opening a possibility of creating a new class of magnetosome-based magnetic biocomposites [24,196-198]. Use of various organic linkers for modifying the magnetosome membrane provides a wide range of applications in the field of targeted therapy in oncology and in gene therapy [199,200]. Compared to synthetic magnetic particles modified with aminosilane, bacterial magnetosomes are characterized by greater thermal effect when heated by a radiofrequency field, at the same time having a much higher lethal dose converted to the mass of magnetite (up to $480 \mathrm{mg}$ per $\mathrm{kg}$ [146]) as compared to synthetic analogs [201]. Bacterial magnetosomes are also toxic at concentrations above $1 \mathrm{mg} / \mathrm{mL}$ against $70-100 \mu \mathrm{g} / \mathrm{mL}$ for synthetic magnetite particles [200,202]. Biocompatibility of magnetosomes can be further increased by removing bacterial endotoxins and forming an additional protein coating [203].

The cytostatic effect in vivo and in vitro with respect to human hepatocellular carcinoma HepG2 cells capable of selectively binding to magnetosomes [204] is higher for the magnetosomes modified with anthracycline drugs, than for drugs not bound to nanoparticles [205]. The effect of targeted gene [206] and chemotherapy [207] with functionalized magnetosomes has also been demonstrated on HepG2 cells. Several characteristics of synthetic magnetic nanoparticles and bacterial magnetosomes are compared in Table 3. 


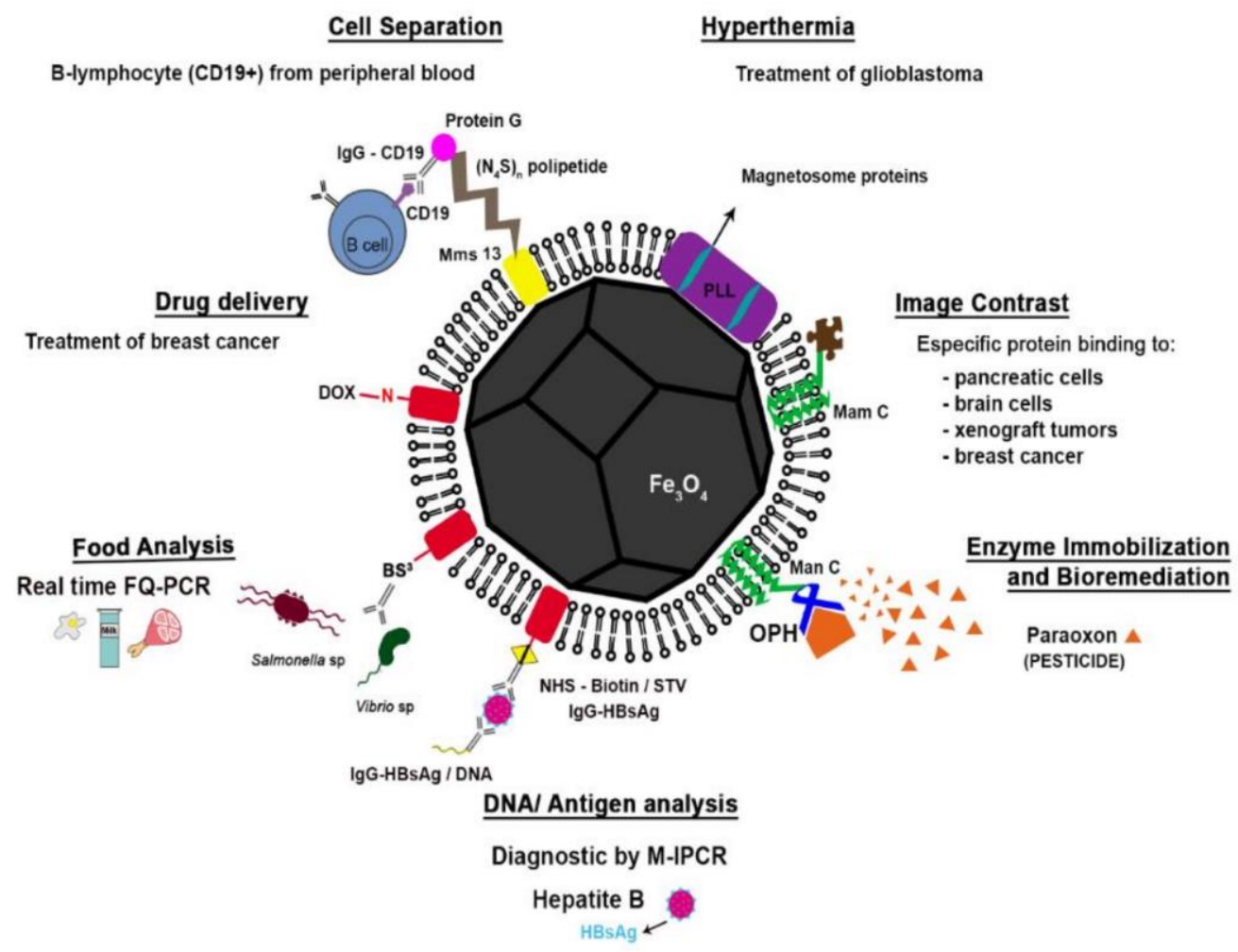

Figure 7. Scheme of a functionalized magnetosome according to various biomedical and biotechnological applications. Drug delivery: the association between the surface proteins of the magnetosome and doxorubicin (DOX), an anti-breast cancer drug. Cell separation: modified magnetosomes were bound to anti-murinic G Ig anti-CD19 and used for separating B-lymphocytes from peripheral blood cells. Food sciences: a capture system with the magnetosome proteins fused using a cross-linking reagent bis (sulfosuccinimidyl) suberate (BS3) for attachment of antibodies to Salmonella and Vibrio species from food samples (e.g., milk, egg, and pork). DNA/Antigen analysis: antibody-functionalized magnetosomes were used for immobilization of HBsAg (hepatitis B antigen) in human serum and enhancement of sensitivity of immunoassay. Image contrast: magnetosomes with specific proteins bound to the surface with high affinity to target cells were used as superparamagnetic contrast agents for magnetic resonance imaging. Hyperthermia: magnetosomes coated with poly-L-lysine (PLL) were used in hyperthermia. Enzyme immobilization and bioremediation: magnetosomes expressing MamC fused with organophosphohydrolase (OPD) from of Flavobacterium sp., were used for the degradation of paraoxon. Reprinted from [24], Vargas, G.; Cypriano, J.; Correa, T.; Leão, P.; Bazylinski, D.A. and Abreu, F. Applications of Magnetotactic Bacteria, Magnetosomes and Magnetosome Crystals in Biotechnology and Nanotechnology: Mini-Review. Molecules 2018, 23, Article 2438, license CC BY 4.0.

Table 3. Comparison of the biological properties of synthetic particles of magnetite and magnetosomes

\begin{tabular}{cccc}
\hline Characteristic & Synthetic Particles ${ }^{\mathbf{1}}$ & Magnetosomes & Refs. \\
\hline Acute toxicity (LD50) in rats, $\mathrm{mg} / \mathrm{kg}$ & $135-180$ & 480 & {$[146,201]$} \\
\hline Cytotoxicity (HUVEC ${ }^{2} \mathrm{MTT}$ assay), $\mathrm{mg} / \mathrm{mL}$ & $0.07-1.0^{3}$ & $0.1-5.1$ & {$[176-178,188,189,200,202]$} \\
\hline Maximum non-hemolytic concentration, $\mathrm{mg} / \mathrm{mL}$ & 3.0 & $1.6-4.0$ & {$[176,189,208]$} \\
\hline Magnetic resonance relaxivity $r_{2}, \mathrm{mM}^{-1} \mathrm{~s}^{-1}$ & $130-170$ & $150-600$ & {$[127,182,187,189,200]$} \\
\hline Specific absorption rate, $\mathrm{kW} / \mathrm{g}$ & $0.6-0.8$ & $0.4-1.4$ & {$[132,183,185,209]$} \\
\hline Minimal biodegradation period, days & 30 & $28-42$ & {$[177,200,201,210]$} \\
\hline Magneto Immuno-PCR limit of detection, $\mathrm{ng} / \mathrm{mL}$ & 8 & 0.32 & {$[191]$} \\
\hline DNA extraction release, $\mu \mathrm{g} / \mathrm{mg}$ & $1.0-2.2$ & $3.0-19.2$ & {$[195]$} \\
\hline
\end{tabular}

\footnotetext{
${ }^{1}$ Dextran coated superparamagnetic iron oxide nanoparticles unless otherwise specified. ${ }^{2}$ Human umbilical vein endothelial cell culture.

${ }^{3}$ Silica-coated magnetite nanoparticles.
} 
In vitro studies have shown that interaction with an alternating magnetic field allows using magnetosomes conjugated with polyclonal antibodies to bind and destroy pathogen cells, in particular Staphylococcus aureus, not via the thermal effect but through the mechanical pressure created by magnetosomes [211]. Due to the ability to biosorb metal ions from an aqueous medium, MTB can be used for environmentally safe biosynthesis of controlled size gold, silver, platinum, and palladium nanoparticles [212].

Chains of magnetosomes provide better inhibition of tumor cells compared to individual magnetosomes due to the absence of aggregates [213]. MRI was applied to monitor the distribution of magnetosomes within the tumor tissue in the course of the therapeutic treatment, and it was shown that inhomogeneous distribution of magnetosomes inside tumor tissue may strongly limit their therapeutic efficacy against glioma [209]. The U87-Luc glioma model was used to demonstrate complete tumor eradication after hyperthermic therapy in 40-50\% of cases, while the magnetosomes themselves were subject to biodegradation over time [214,215]. Nevertheless, the clinical use of magnetosomes has not been described so far due to incomplete tests on biocompatibility and pharmacokinetics in vivo $[183,216,217]$.

\section{Conclusions}

Based on the analysis of scientific publications on the cultivation and the physicochemical and biological properties of magnetotactic bacteria and magnetosomes, we can outline some of the most active research directions in this field.

Despite the long time since the discovery of MTB, many important aspects for understanding the mechanisms of biomineralization such as the kinetics and dynamics of the crystallization of magnetite and greigite, reasons for the predominance of the main types of faceting and the aspect ratio of crystals, the presence of natural alloying elements in magnetite are yet insufficiently studied. Furthermore, these studies have only been carried out for a small number of MTB types. The difference in the magnetic and, generally, electromagnetic properties of magnetosomes isolated from different MTB therefore remains a vibrant research field. There exist considerable differences in the magnetic properties of bacterial magnetosomes and their synthetic counterparts, which are actively studied on the crossroads of rock and mineral magnetism, physics of magnetic materials, and nanotechnology.

Along with the continuing interest in the fundamental physical and chemical properties of MTB and magnetosomes, a growing number of studies is seen to explore their practical applications in biomedicine and biotechnology. This is dictated, on the one hand, by the ability to use magnetosomes as a base element for design of new theranostic agents and their high biocompatibility, which is unattainable for present-day synthetic counterparts, and, on the other hand, by the need for joint efforts of specialists in related fields of knowledge, such as genetic engineering, chemistry of nanosystems, micromagnetism, and microfluidics.

In our view, the most important directions for MTB research in the near future will be the further development of the technology of high-performance automated fermentation of genetically modified strains with improved biocompatibility and, possibly, superparamagnetic properties. Detailed studies of the mechanisms of biomineralization of magnetite would provide a basis for developing methods for the synthesis of biomimetic magnetic nanoparticles providing much higher productivity and maintaining high biological characteristics. In addition, in the field of paleomagnetism, it is important to consider bacterial magnetite in the framework of broad comparative rock-magnetic studies of the biogenic magnetic minerals of bacteria, protists, and other single-celled organisms.

Author Contributions: K.G.G., Conceptualization, Writing-Original Draft; D.S.G., Writing-Review \& Editing; P.V.K., Writing-Review \& Editing; A.K., Writing-Review \& Editing; V.V.K., WritingReview \& Editing; E.S.S., Writing-Review \& Editing; M.A.S., Writing-Review \& Editing. All authors have read and agreed to the published version of the manuscript. 
Funding: This work received no external funding.

Institutional Review Board Statement: Not applicable.

Informed Consent Statement: Not applicable.

Data Availability Statement: The data that support the finding of this research are not publicly available due to confidentiality constraints.

Conflicts of Interest: The authors declare no conflict of interest.

\section{References}

1. Kirshvink, J.L. (Ed.) Magnetite Biomineralization and Magnetoreception in Organisms. A New Biomagnetism; Plenum Press: New York, NY, USA, 1985; pp. 16-17.

2. Goldhawk, D.E.; Gelman, N.; Thompson, R.T.; Prato, F.S. Forming magnetosome-like nanoparticles in mammalian cells for molecular MRI. In Design and Applications of Nanoparticles in Biomedical Imaging; Springer: Cham, Switzerland, 2016.

3. Konhauser, K.O. Bacterial iron biomineralisation in nature. FEMS Microbiol. Rev. 1997, 20, 315-326. [CrossRef]

4. Revati, K.; Pandey, B.D. Microbial synthesis of iron-based nanomaterials-A review. Bull. Mater. Sci. 2011, 34, 191-198. [CrossRef]

5. Faivre, D. Iron Oxides. From Nature to Applications; Wiley-VCH Verlag GmbH \& Co. KGaA: Weinheim, Germany, 2016 ; p. 106.

6. Joudeikis, R. Engineering Membranes in Escherichia coli: The Magnetosome, LemA Protein Family and Outer Membrane Vesicles. Ph.D. Thesis, University of Kent, Canterbury, UK, 2016; p. 8.

7. Uebe, R.; Schuler, D. Magnetosome biogenesis in magnetotactic bacteria. Nat. Rev. Microbiol. 2016, 14, 621-637. [CrossRef]

8. Blakemore, R. Magnetotactic bacteria. Science 1975, 190, 377-379. [CrossRef]

9. Blakemore, R.P. Magnetotactic bacteria. Ann. Rev. Microbiol. 1982, 36, 217-238. [CrossRef]

10. Faivre, D.; Schuler, D. Magnetotactic bacteria and magnetosomes. Chem. Rev. 2008, 108, 4875-4898. [CrossRef]

11. Correa, T.N.; Taveira, I.N.; de Souza Filho, R.P.; de Avila Abreu, F. Biomineralization of magnetosomes: Billion-year evolution shaping modern nanotools [online first]. In Biomineralization; IntechOpen: London, UK, 2020; p. 2. [CrossRef]

12. Bazylinski, D.; Heywood, B.R.; Mann, S.; Frankel, R.B. $\mathrm{Fe}_{3} \mathrm{O}_{4}$ and $\mathrm{Fe}_{3} \mathrm{~S}_{4}$ in a bacterium. Nature 1993, 366, 218. [CrossRef]

13. Schuler, D. (Ed.) Magnetoreception and Magnetosomes in Bacteria; Springer: Berlin, Germany, 2007; p. 80.

14. Kopp, R.E.; Kirschvink, J.L. The identification and biogeochemical interpretation of fossil magnetotactic bacteria. Earth-Sci. Rev. 2008, 86, 42-61. [CrossRef]

15. Li, J.; Benzerara, K.; Bernard, B.; Beyssac, O. The link between biomineralization and fossilization of bacteria: Insights from field and experimental studies. Chem. Geol. 2013, 359, 49-69. [CrossRef]

16. Frankel, R.B.; Blakemore, R.P. (Eds.) Iron Biominerals; Springer: Boston, MA, USA, 1991; p. 79.

17. Yan, L.; Zhang, S.; Chen, P.; Liu, H.; Yin, H.; Li, H. Magnetotactic bacteria, magnetosomes and their application. Microbiol. Res. 2012, 167, 507-519. [CrossRef] [PubMed]

18. Rosenberg, E. (Ed.) The Prokaryotes; Springer: Berlin, Germany, 2013; p. 473.

19. Lefèvre, C.T.; Bazylinski, D.A. Ecology, diversity, and evolution of magnetotactic bacteria. Microbiol. Mol. Biol. Rev. 2013, 77, 497-526. [CrossRef] [PubMed]

20. Uzun, M.; Alekseeva, L.; Krutkina, M.; Koziaeva, V.; Grouzdev, D. Unravelling the diversity of magnetotactic bacteria through analysis of open genomic databases. Sci. Data 2020, 7, 252. [CrossRef]

21. Lin, W.; Zhang, W.; Paterson, G.A.; Zhu, Q.; Zhao, X.; Knight, R.; Bazylinski, D.A.; Roberts, A.P.; Pan, Y. Expanding magnetic organelle biogenesis in the domain Bacteria. Microbiome 2020, 8, 152. [CrossRef]

22. Koziaeva, V.V.; Rusakova, S.A.; Slobodova, N.V.; Uzun, M.; Kolganova, T.V.; Skryabin, K.G.; Grouzdev, D.S. Magnetospirillum kuznetsovii sp. nov., a novel magnetotactic bacterium isolated from a lake in the Moscow region. Int. J. Syst. Evol. Microbiol. 2019, 69, 1953-1959. [CrossRef]

23. Xie, J.; Chen, K.; Chen, X. Production, modification and bio-applications of magnetic nanoparticles gestated by magnetotactic bacteria. Nano Res. 2009, 2, 261-278. [CrossRef]

24. Vargas, G.; Cypriano, J.; Correa, T.; Leão, P.; Bazylinski, D.A.; Abreu, F. Applications of magnetotactic bacteria, magnetosomes and magnetosome crystals in biotechnology and nanotechnology: Mini-review. Molecules 2018, 23, 2438. [CrossRef] [PubMed]

25. Yan, L.; Da, H.; Zhang, S.; López, V.M.; Wang, W. Bacterial magnetosome and its potential application. Microbiol. Res. 2017, 203, 19-28. [CrossRef]

26. Nanda, T.; Rathore, A.; Sharma, D. Biomineralized and chemically synthesized magnetic nanoparticles: A contrast. Front. Mater. Sci. 2020, 14, 387-401. [CrossRef]

27. Prozorov, T.; Bazylinski, D.A.; Mallapragada, S.K.; Prozorov, R. Novel magnetic nanomaterials inspired by magnetotactic bacteria: Topical review. Mater. Sci. Eng. R 2013, 74, 133-172. [CrossRef]

28. Majidi, S.; Sehrig, F.Z.; Farkhani, S.M.; Goloujeh, M.S.; Akbarzadeh, A. Current methods for synthesis of magnetic nanoparticles. Artif. Cells Nanomed. Biotechnol. 2016, 44, 722-734. [CrossRef]

29. Joshi, N.; Filip, J.; Coker, V.S.; Sadhukhan, J.; Safarik, I.; Bagshaw, H.; Lloyd, J.R. Microbial reduction of natural Fe(III) Minerals; Toward the sustainable production of functional magnetic nanoparticles front. Environ. Sci. 2018, 6, 127. [CrossRef] 
30. Bain, J.; Legge, C.J.; Beattie, D.L.; Sahota, A.; Dirks, C.; Lovett, J.R.; Staniland, S.S. A biomimetic magnetosome: Formation of iron oxide within carboxylic acid terminated polymersomes. Nanoscale 2019, 11, 11617-11625. [CrossRef]

31. de Walle, A.V.; Sangnier, A.P.; Abou-Hassan, A.; Curcio, A.; Hémadi, M.; Menguy, N.; Lalatonne, Y.; Luciani, N.; Wilhelm, C. Biosynthesis of magnetic nanoparticles from nanodegradation products revealed in human stem cells. Proc. Natl. Acad. Sci. USA 2019, 116, 4044-4053. [CrossRef]

32. Komeili, A. Molecular mechanisms of magnetosome formation. Annu. Rev. Biochem. 2007, 76, 351-366. [CrossRef] [PubMed]

33. Lefèvre, C.T.; Bennet, M.; Landau, L.; Vach, P.; Pignol, D.; Bazylinski, D.A.; Frankel, R.B.; Klumpp, S.; Faivre, D. Diversity of magneto-aerotactic behaviors and oxygen sensing mechanisms in cultured magnetotactic bacteria. Biophys. J. 2014, 107, 527-538. [CrossRef]

34. Sharma, M.; Naresh, M.; Mittal, A. Morphological changes in magnetotactic bacteria in presence of magnetic fields. J. Biomed. Nanotechnol. 2007, 3, 1-6. [CrossRef]

35. Dziuba, M.V.; Kolganova, T.V.; Gorlenko, V.M.; Kuznetsov, B.B. Species diversity of magnetotactic bacteria from the ol'khovka river, Russia. Microbiology 2013, 82, 335-340. [CrossRef]

36. McCausland, H.C.; Komeili, A. Magnetic genes: Studying the genetics of biomineralization in magnetotactic bacteria. PLoS Genet. 2020, 16, e1008499. [CrossRef]

37. Amor, M.; Busigny, V.; Louvat, P.; Tharaud, M.; Gelabert, A.; Cartigny, P.; Carlut, J.; Isambert, A.; Durand-Dubief, M.; OnaNguema, G.; et al. Iron uptake and magnetite biomineralization in the magnetotactic bacterium Magnetospirillum magneticum strain AMB-1: An iron isotope study. Geochim. Cosmochim. Acta 2018, 232, 225-243. [CrossRef]

38. Greene, S.E.; Komeili, A. Biogenesis and subcellular organization of the magnetosome organelles of magnetotactic bacteria. Curr. Opin. Cell Biol. 2012, 24, 490-495. [CrossRef] [PubMed]

39. Amor, M.; Ceballos, A.; Wan, J.; Simon, C.P.; Aron, A.T.; Chang, C.J.; Hellman, F.; Komeili, A. Magnetotactic bacteria accumulate a large pool of iron distinct from their magnetite crystals. Appl. Environ. Microbiol. 2020, 86, e01278-20. [CrossRef] [PubMed]

40. Niu, W.; Zhang, Y.; Liu, J.; Wen, T.; Miao, T.; Basit, A.; Jiang, W. OxyR controls magnetosome formation by regulating magnetosome island (MAI) genes, iron metabolism, and redox state. Free Radic. Biol. Med. 2020, 161, 272-282. [CrossRef] [PubMed]

41. Chen, H.; Li, K.; Cai, Y.; Wang, P.; Gong, W.; Wu, L.-F.; Song, T. Light regulation of resistance to oxidative damage and magnetic crystal biogenesis in Magnetospirillum magneticum mediated by a Cys-less LOV-like protein. Appl. Microbiol. Biotechnol. 2020, 104, 7927-7941. [CrossRef]

42. Guo, F.F.; Yang, W.; Jiang, W.; Geng, S.; Peng, T.; Li, J.L. Magnetosomes eliminate intracellular reactive oxygen species in Magnetospirillum gryphiswaldense MSR-1. Environ. Microbiol. 2012, 14, 1722-1729. [CrossRef] [PubMed]

43. Muñoz, D.; Marcano, L.; Martín-Rodríguez, R.; Simonelli, L.; Serrano, A.; García-Prieto, A.; Fdez-Gubieda, M.L.; Muela, A. Magnetosomes could be protective shields against metal stress in magnetotactic bacteria. Sci. Rep. 2020, 10, 11430. [CrossRef] [PubMed]

44. Lower, B.H.; Bazylinski, D.A. The bacterial magnetosome: A unique prokaryotic organelle. J. Mol. Microbiol. Biotechnol. 2013, 23, 63-80. [CrossRef] [PubMed]

45. Schübbe, S.; Williams, T.J.; Xie, G.; Kiss, H.E.; Brettin, T.S.; Martinez, D.; Ross, C.A.; Schüler, D.; Cox, D.B.; Nealson, K.H.; et al. Complete genome sequence of the chemolithoautotrophic marine magnetotactic coccus strain MC-1. Appl. Environ. Microbiol. 2009, 75, 4835-4852. [CrossRef] [PubMed]

46. Nakazawa, H.; Arakaki, A.; Narita-Yamada, S.; Yashiro, I.; Jinno, K.; Aoki, N.; Tsuruyama, A.; Okamura, Y.; Tanikawa, S.; Fujita, $\mathrm{N}$; ; et al. Whole genome sequence of Desulfovibrio magneticus strain RS-1 revealed common gene clusters in magnetotactic bacteria. Genome Res. 2009, 19, 1801-1808. [CrossRef]

47. Abreu, F.; Morillo, V.; Nascimento, F.; Werneck, C.; Cantão, M.E.; Ciapina, L.P.; de Almeida, L.C.P.; Lefèvre, C.T.; Bazylinski, D.A.; de Vasconcelos, A.T.R.; et al. Deciphering unusual uncultured magnetotactic multicellular prokaryotes through genomics. ISME J. 2014, 8, 1055-1068. [CrossRef]

48. Kolinko, S.; Jogler, C.; Katzmann, E.; Wanner, G.; Peplies, J.; Schüler, D. Single-cell analysis reveals a novel uncultivated magnetotactic bacterium within the candidate division OP3. Environ. Microbiol. 2012, 14, 1709-1721. [CrossRef]

49. Koziaeva, V.; Dziuba, M.; Leão, P.; Uzun, M.; Krutkina, M.; Grouzdev, D. Genome-Based Metabolic Reconstruction of a Novel Uncultivated Freshwater Magnetotactic coccus "Ca. Magnetaquicoccus inordinatus" UR-1, and Proposal of a Candidate Family “Ca. Magnetaquicoccaceae. Front. Microbiol. 2019, 10, 2290. [CrossRef]

50. Zhang, W.; Ji, R.; Liu, J.; Pan, Y.; Wu, L.-F.; Lin, W. Two Metagenome-Assembled Genome Sequences of Magnetotactic Bacteria in the Order Magnetococcales. Microbiol. Resour. Announc. 2020, 9, e00363-20. [CrossRef]

51. Monteil, C.L.; Grouzdev, D.S.; Perriere, G.; Alonso, B.; Rouy, Z.; Cruveiller, S.; Ginet, N.; Pignol, D.; Lefèvre, C.T. Repeated horizontal gene transfers triggered parallel evolution of magnetotaxis in two evolutionary divergent lineages of magnetotactic bacteria. ISME J. 2020, 14, 1783-1794. [CrossRef]

52. Liu, P.; Liu, Y.; Zhao, X.; Roberts, A.P.; Zhang, H.; Zheng, Y.; Wang, F.; Wang, L.; Menguy, N.; Pan, Y.; et al. Diverse phylogeny and morphology of magnetite biomineralized by magnetotactic cocci. Environ. Microbiol. 2021, 23, 1115-1129. [CrossRef]

53. Lefèvre, C.T.; Menguy, N.; Abreu, F.; Lins, U.; Pósfai, M.; Prozorov, T.; Pignol, D.; Frankel, R.B.; Bazylinski, D.A. A cultured greigite-producing magnetotactic bacterium in a novel group of sulfate-reducing bacteria. Science 2011, 334, 1720-1723. [CrossRef] 
54. Koziaeva, V.V.; Dziuba, M.V.; Ivanov, T.M.; Kuznetsov, B.B.; Skryabin, K.G.; Grouzdev, D.S. Draft genome sequences of two magnetotactic bacteria, Magnetospirillum moscoviense BB-1 and Magnetospirillum marisnigri SP-1. Genome Announc. 2016, 4, e00814-16. [CrossRef] [PubMed]

55. Trubitsyn, D.; Abreu, F.; Ward, F.B.; Taylor, T.; Hattori, M.; Kondo, S.; Trivedi, U.; Staniland, S.; Lins, U.; Bazylinski, D.A. Draft genome sequence of Magnetovibrio blakemorei strain MV-1, a marine vibrioid magnetotactic bacterium. Genome Announc. 2016, 4, e01330-16. [CrossRef]

56. Grouzdev, D.S.; Dziuba, M.V.; Sukhacheva, M.S.; Mardanov, A.V.; Beletskiy, A.V.; Kuznetsov, B.B.; Skryabin, K.G. Draft genome sequence of Magnetospirillum sp. strain SO-1, a freshwater magnetotactic bacterium isolated from the Ol'khovka River, Russia. Genome Announc. 2014, 2, e00235-14. [CrossRef] [PubMed]

57. Monteil, C.L.; Benzerara, K.; Menguy, N.; Bidaud, C.C.; Michot-Achdjian, E.; Bolzoni, R.; Mathon, F.P.; Coutaud, M.; Alonso, B.; Garau, C.; et al. Intracellular amorphous Ca-carbonate and magnetite biomineralization by a magnetotactic bacterium affiliated to the Alphaproteobacteria. ISME J. 2021, 15, 1-18. [CrossRef] [PubMed]

58. Ke, L.; Liu, P.; Liu, S.; Gao, M. Complete genome sequence of Magnetospirillum sp. ME-1, a novel magnetotactic bacterium isolated from East Lake, Wuhan, China. Genome Announc. 2017, 5, e00485-17. [CrossRef]

59. Uebe, R.; Schüler, D.; Jogler, C.; Wiegand, S. Reevaluation of the complete genome sequence of Magnetospirillum gryphiswaldense MSR-1 with single-molecule real-time sequencing data. Genome Announc. 2018, 6, e00309-18. [CrossRef] [PubMed]

60. Smalley, M.D.; Marinov, G.K.; Bertani, L.E.; DeSalvo, G. Genome sequence of Magnetospirillum magnetotacticum strain MS-1. Genome Announc. 2015, 3, e00233-15. [CrossRef] [PubMed]

61. Lefèvre, C.T.; Wu, L.-F. Evolution of the bacterial organelle responsible for magnetotaxis. Trends Microbiol. 2013, 21, 534-543. [CrossRef]

62. Nudelman, H.; Zarivach, R. Structure prediction of magnetosome-associated proteins. Front. Microbiol. 2014, 5, 9. [CrossRef]

63. Lohße, A.; Ullrich, S.; Katzmann, E.; Borg, S.; Wanner, G.; Richter, M.; Voigt, B.; Schweder, T.; Schüler, D. Functional analysis of the magnetosome island in magnetospirillum gryphiswaldense: The mamAB operon is sufficient for magnetite biomineralization. PLoS ONE 2011, 6, e25561. [CrossRef]

64. Murat, D.J. Magnetosomes: How do they stay in shape? Mol. Microbiol. Biotechnol. 2013, 23, 81-94. [CrossRef]

65. Rahn-Lee, L.; Komeili, A. The magnetosome model: Insights into the mechanisms of bacterial biomineralization. Front. Microbiol. 2013, 4, 352. [CrossRef]

66. Barber-Zucker, S.; Zarivach, R. A look into the biochemistry of magnetosome biosynthesis in magnetotactic bacteria. ACS Chem. Biol. 2017, 12, 13-22. [CrossRef]

67. Raschdorf, O.; Forstner, Y.; Kolinko, I.; Uebe, R.; Plitzko, J.M.; Schüler, D. Genetic and ultrastructural analysis reveals the key players and initial steps of bacterial magnetosome membrane biogenesis. PLoS Genet. 2016, 12, e1006101. [CrossRef] [PubMed]

68. Yang, J.; Li, S.; Huang, X.; Li, J.; Li, L.; Pan, Y.; Li, Y. MamX encoded by the mamXY operon is involved in control of magnetosome maturation in Magnetospirillum gryphiswaldense MSR-1. BMC Microbiol. 2013, 13, 203. [CrossRef] [PubMed]

69. Toro-Nahuelpan, M.; Giacomelli, G.; Raschdorf, O.; Borg, S.; Plitzko, J.M.; Bramkamp, M.; Schüler, D.; Müller, F.D. MamY is a membrane-bound protein that aligns magnetosomes and the motility axis of helical magnetotactic bacteria. Nat. Microbiol. 2019, 4, 1978-1989. [CrossRef] [PubMed]

70. Devouard, B.; Pósfai, M.; Hua, X.; Bazylinski, D.A.; Frankel, R.B.; Buseck, P.R. Magnetite from magnetotactic bacteria: Size distributions and twinning. Am. Mineral. 1998, 83, 1387-1398. [CrossRef]

71. Schuler, D. Genetics and cell biology of magnetosome formation in magnetotactic bacteria. FEMS Microbiol. Rev. 2008, 32, 654-672. [CrossRef] [PubMed]

72. Abraçado, L.G.; Abreu, F.; Keim, C.N.; Campos, A.P.C.; Lins, U.; Farina, M. Magnetosome chain superstructure in uncultured magnetotactic bacteria. Phys. Biol. 2010, 7, 046016. [CrossRef]

73. Komeili, A.; Li, Z.; Newman, D.K.; Jensen, G.J. Magnetosomes are cell membrane invaginations organized by the actin-like protein MamK. Science 2006, 311, 242-245. [CrossRef] [PubMed]

74. Abreu, F.; Sousa, A.A.; Aronova, M.A.; Kim, Y.; Cox, D.; Leapman, R.D.; Andrade, L.R.; Kachar, B.; Bazylinski, D.A.; Lins, U. Cryo-electron tomography of the magnetotactic vibrio Magnetovibrio blakemorei: Insights into the biomineralization of prismatic magnetosomes. J. Struct. Biol. 2013, 181, 162-168. [CrossRef]

75. Stephens, C. Bacterial cell biology: Managing magnetosomes. Curr. Biol. 2006, 16, R363-R365. [CrossRef]

76. Le Nagard, L.; Morillo-López, V.; Fradin, C.; Bazylinski, D.A. Growing magnetotactic bacteria of the genus magnetospirillum: Strains MSR-1, AMB-1 and MS-1. J. Vis. Exp. 2018, 140, e58536. [CrossRef] [PubMed]

77. Paterson, G.A.; Wang, Y.; Pan, Y. The fidelity of paleomagnetic records carried by magnetosome chains. Earth Planet. Sci. Lett. 2013, 383, 82-91. [CrossRef]

78. Li, J.; Cai, F.; Lv, H.; Sun, J. Selective Competitive Biosorption of Au(III) and Cu(II) in Binary Systems by Magnetospirillum gryphiswaldense. Sep. Sci. Technol. 2013, 48, 960-967. [CrossRef]

79. Vali, H.; Förster, O.; Amarantidis, G.; Petersen, N. Magnetotactic bacteria and their magnetofossils in sediments. Earth Planet. Sci. Lett. 1987, 86, 389-400. [CrossRef]

80. Lins, U.; McCartney, M.R.; Farina, M.; Frankel, R.B.; Buseck, P.R. Crystal habits and magnetic microstructures of magnetosomes in coccoid magnetotactic bacteria. An. Acad. Bras. Ciências 2006, 78, 463-474. [CrossRef] [PubMed] 
81. Lins, U.; McCartney, M.R.; Farina, M.; Frankel, R.B.; Buseck, P.R. Habits of magnetosome crystals in coccoid magnetotactic bacteria. Appl. Environ. Microbiol. 2005, 71, 4902-4905. [CrossRef]

82. Moskowitz, B.M.; Frankel, R.B.; Bazylinski, D.A. Rock magnetic criteria for the detection of biogenic magnetite. Earth Planet. Sci. Lett. 1993, 120, 283-300. [CrossRef]

83. Scheffel, A.; Gärdes, A.; Grünberg, K.; Wanner, G.; Schüler, D. The major magnetosome proteins MamGFDC are not essential for magnetite biomineralization in magnetospirillum gryphiswaldense but regulate the size of magnetosome crystals. J. Bacteriol. 2008, 190, 377-386. [CrossRef]

84. Uebe, R.; Keren-Khadmy, N.; Zeytuni, N.; Katzmann, E.; Navon, Y.; Davidov, G.; Bitton, R.; Plitzko, J.M.; Schüler, D.; Zarivach, R. The dual role of MamB in magnetosome membrane assembly and magnetite biomineralization. Mol. Microbiol. $2018,107,542-557$. [CrossRef]

85. Bender, P.; Marcano, L.; Orue, I.; Venero, D.A.; Honecker, D.; Barquín, L.F.; Muela, A.; Fdez-Gubieda, M.L. Probing the stability and magnetic properties of magnetosome chains in freeze-dried magnetotactic bacteria. Nanoscale Adv. 2020, 2, 1115-1121. [CrossRef]

86. Chariaou, M.; Rahn-Lee, L.; Kind, J.; García-Rubio, I.; Komeili, A.; Gehring, A.U. Anisotropy of bullet-shaped magnetite nanoparticles in the magnetotactic bacteria desulfovibrio magneticus sp. Strain RS-1. Biophys. J. 2015, 108, 1268-1274. [CrossRef] [PubMed]

87. Li, J.; Menguy, N.; Gatel, C.; Boureau, V.; Snoeck, E.; Patriarche, G.; Leroy, E.; Pan, Y. Crystal growth of bullet-shaped magnetite in magnetotactic bacteria of the Nitrospirae phylum. J. R. Soc. Interface 2014, 12, 20141288. [CrossRef]

88. Pan, Y.; Petersen, N.; Davila, A.F.; Zhang, L.; Winklhofer, M.; Liu, Q.; Hanzlik, M.; Zhu, R. The detection of bacterial magnetite in recent sediments of Lake Chiemsee (southern Germany). Earth Planet. Sci. Lett. 2005, 232, 109-123. [CrossRef]

89. Pan, Y.; Petersen, N.; Winklhofer, M.; Davila, A.F.; Liu, Q.; Frederichs, T.; Hanzlik, M.; Zhu, R. Rock magnetic properties of uncultured magnetotactic bacteria. Earth Planet. Sci. Lett. 2005, 237, 311-325. [CrossRef]

90. Nguyen, H.V.; Suzuki, E.; Oestreicher, Z.; Minamide, H.; Endoh, H.; Fukumori, Y.; Taoka, A. A protein-protein interaction in magnetosomes: TPR protein MamA interacts with an Mms6 protein. Biochem. Biophys. Rep. 2016, 7, 39-44. [CrossRef] [PubMed]

91. Nudelman, H.; Valverde-Tercedor, C.; Kolusheva, S.; Gonzalez, T.P.; Widdrat, M.; Grimberg, N.; Levi, H.; Nelkenbaum, O.; Davidov, G.; Faivre, D.; et al. Structure-function studies of the magnetite-biomineralizing magnetosome-associated protein MamC. J. Struct. Biol. 2016, 194, 244-252. [CrossRef] [PubMed]

92. Cornejo-Warner, E.J. Magnetosome Biogenesis in Magnetospirillum Magneticum AMB-1. Ph.D. Thesis, University of California, Berkeley, CA, USA, 2016; p. 17.

93. Pfeiffer, D.; Toro-Nahuelpan, M.; Bramkamp, M.; Plitzko, J.M.; Schüler, D. The polar organizing protein PopZ is fundamental for proper cell division and segregation of cellular content in magnetospirillum gryphiswaldense. mBio 2019, 10, e02716-18. [CrossRef] [PubMed]

94. Dziuba, M.V.; Zwiener, T.; Uebe, R.; Schüler, D. Single-step transfer of biosynthetic operons endows a non-magnetotactic Magnetospirillum strain from wetland with magnetosome biosynthesis. Environ. Microbiol. 2020, 22, 1603-1618. [CrossRef]

95. Kolinko, I.; Lohße, A.; Borg, S.; Raschdorf, O.; Jogler, C.; Tu, Q.; Pósfai, M.; Tompa, E.; Plitzko, J.M.; Brachmann, A.; et al. Biosynthesis of magnetic nanostructures in a foreign organism by transfer of bacterial magnetosome gene clusters. Nat. Nanotechnol. 2014, 9, 193-197. [CrossRef]

96. Mickoleit, F.; Borkner, C.B.; Toro-Nahuelpan, M.; Herold, H.M.; Maier, D.S.; Plitzko, J.M.; Scheibel, T.; Schüler, D. In vivo coating of bacterial magnetic nanoparticles by magnetosome expression of spider silk-inspired peptides. Biomacromolecules 2018, 19, 962-972. [CrossRef]

97. Peigneux, A.; Jabalera, Y.; Fernández Vivas, M.A.; Casares, S.; Azuaga, A.I.; Jimenez-Lopez, C. Tuning properties of biomimetic magnetic nanoparticles by combining magnetosome associated proteins. Sci. Rep. 2019, 9, 8804. [CrossRef]

98. Staniland, S.S.; Rawlings, A.E. Crystallizing the function of the magnetosome membrane mineralization protein Mms6. Biochem. Soc. Trans. 2016, 44, 883-890. [CrossRef]

99. Prabhu, N.N.; Kowshik, M. Techniques for the isolation of magnetotactic bacteria. J. Microb. Biochem. Technol. 2016, 8, 188-194. [CrossRef]

100. Basit, A.; Wang, J.; Guo, F.; Niu, W.; Jiang, W. Improved methods for mass production of magnetosomes and applications: A review. Microb. Cell Fact. 2020, 19, 197. [CrossRef]

101. Byrne, J.M.; Muhamadali, H.; Coker, V.S.; Cooper, J.; Lloyd, J.R. Scale-up of the production of highly reactive biogenic magnetite nanoparticles using Geobacter sulfurreducens. J. R. Soc. Interface 2015, 12, 20150240. [CrossRef] [PubMed]

102. Gorby, Y.A. Regulation of Magnetosome Biogenesis by Oxygen and Nitrogen. Ph.D. Thesis, University of New Hampshire, Durham, NH, USA, 1989; p. 12.

103. Fernández-Castané, A.; Lia, H.; Thomas, O.R.T.; Overton, T.W. Development of a simple intensified fermentation strategy for growth of Magnetospirillum gryphiswaldense MSR-1: Physiological responses to changing environmental conditions. New Biotechnol. 2018, 46, 22-30. [CrossRef] [PubMed]

104. Fernández-Castané, A.; Li, H.; Thomas, O.R.T.; Overton, T.W. Flow cytometry as a rapid analytical tool to determine physiological responses to changing O2 and iron concentration by Magnetospirillum. Sci. Rep. 2017, 7, 13118. [CrossRef]

105. Moskowitz, B.M.; Frankel, R.B.; Flanders, P.J.; Blakemore, R.P.; Schwartz, B.B. Magnetic properties of magnetotactic bacteria. J. Magn. Magn. Mater. 1988, 73, 273-288. [CrossRef] 
106. Kopp, R.E.; Nash, C.Z.; Kobayashi, A.; Weiss, B.P.; Bazylinski, D.A.; Kirschvink, J.L. Ferromagnetic resonance spectroscopy for assessment of magnetic anisotropy and magnetostatic interactions: A case study of mutant magnetotactic bacteria. J. Geophys. Res. 2006, 111, B12S25. [CrossRef]

107. Kopp, R.E.; Weiss, B.P.; Maloof, A.C.; Vali, H.; Nash, C.Z.; Kirschvink, J.L. Chains, clumps, and strings: Magnetofossil taphonomy with ferromagnetic resonance spectroscopy. Earth Planet. Sci. Lett. 2006, 247, 10-25. [CrossRef]

108. Ionescu, A.; Darton, N.J.; Vyas, K.; Llandro, J. Detection of endogenous magnetic nanoparticles with a tunnelling magnetoresistance sensor. Philos. Trans. Math. Phys. Eng. Sci. 2010, 368, 4371-4387. [CrossRef]

109. Bazylinski, D.A.; Garratt-Reed, A.J.; Frankel, R.B. Electron microscopic studies of magnetosomes in magnetotactic bacteria. Microsc. Res. Tech. 1994, 27, 389-401. [CrossRef]

110. Blondeau, M.; Guyodo, Y.; Guyot, F.; Gatel, C.; Menguy, N.; Chebbi, I.; Haye1, B.; Durand-Dubief, M.; Alphandery, E.; Brayner, R.; et al. Magnetic-field induced rotation of magnetosome chains in silicified magnetotactic bacteria. Sci. Rep. 2018, 8, 7699. [CrossRef]

111. Li, J.; Menguy, N.; Arrio, M.-A.; Sainctavit, P.; Juhin, A.; Wang, Y.; Chen, H.; Bunau, O.; Otero, E.; Ohresser, P.; et al. Controlled cobalt doping in the spinel structure of magnetosome magnetite: New evidences from element- and site-specific $\mathrm{X}$-ray magnetic circular dichroism analyses. J. R. Soc. Interface 2016, 13, 20160355. [CrossRef]

112. Fischer, H.; Mastrogiacomo, G.; Löffler, J.F.; Warthmann, R.J.; Weidler, P.G.; Gehring, A.U. Ferromagnetic resonance and magnetic characteristics of intact magnetosome chains in Magnetospirillum gryphiswaldense. Earth Planet. Sci. Lett. 2008, 270, 200-208. [CrossRef]

113. Gehring, A.U.; Charilaou, M.; García-Rubio, I. Oxidized magnetosomes in magnetotactic bacteria. J. Magn. Magn. Mater. 2012, 324, 1281-1284. [CrossRef]

114. Gehring, A.U.; Fischer, H.; Charilaou, M.; García-Rubio, I. Magnetic anisotropy and Verwey transition of magnetosome chains in Magnetospirillum gryphiswaldense. Geophys. J. Int. 2011, 187, 1215-1221. [CrossRef]

115. Gehring, A.U.; Kind, J.; Charilaou, M.; García-Rubio, I. The detection of magnetotactic bacteria and magnetofossils by means of magnetic anisotropy. Earth Planet. Sci. Lett. 2011, 309, 113-117. [CrossRef]

116. Zhang, T.; Pan, Y. Constraining the magnetic properties of ultrafine- and fine-grained biogenic magnetite. Earth Planets Space 2018, 70, 206. [CrossRef]

117. Ding, Y.; Li, J.; Liu, J.; Yang, J.; Jiang, W.; Tian, J.; Li, Y.; Pan, Y.; Li, J. Deletion of the ftsZ-like gene results in the production of superparamagnetic magnetite magnetosomes in magnetospirillum gryphiswaldense. J. Bacteriol. 2010, 192, 1097-1105. [CrossRef]

118. Prozorov, R.; Prozorov, T.; Mallapragada, S.K.; Narasimhan, B. Magnetic irreversibility and the Verwey transition in nanocrystalline bacterial magnetite. Phys. Rev. B 2007, 76, 054406. [CrossRef]

119. Muxworthy, A.R.; Williams, W. Critical superparamagnetic/single-domain grain sizes in interacting magnetite particles: Implications for magnetosome crystals. J. R. Soc. Interface 2009, 6, 1207-1212. [CrossRef]

120. Newell, A.J. Transition to superparamagnetism in chains of magnetosome crystals. Geochem. Geophys. Geosyst. 2009, 10, Q11Z08. [CrossRef]

121. Firlar, E.; Perez-Gonzalez, T.; Olszewska, A.; Faivre, D. Following iron speciation in the early stages of magnetite magnetosome biomineralisation. J. Mater. Res. 2016, 31, 547-555. [CrossRef]

122. Wang, X.K.; Ma, Q.F.; Jiang, W.; Lv, J.; Pan, W.D.; Song, T.; Wu, L.-F. Effects of Hypomagnetic Field on Magnetosome Formation of Magnetospirillum Magneticum AMB-1. Geomicrobiol. J. 2008, 25, 296-303. [CrossRef]

123. Lins, U.; Freitas, F.; Keim, C.N.; Farina, M. Electron Spectroscopic Imaging of Magnetotactic Bacteria: Magnetosome Morphology and Diversity. Microsc. Microanal. 2000, 6, 463-470. [CrossRef] [PubMed]

124. Schuler, D.; Frankel, R.B. Bacterial magnetosomes: Microbiology, biomineralisation and biotechnological applications. Appl. Microbiol. Biotechnol. 1999, 52, 464-473. [CrossRef] [PubMed]

125. Kalirai, S.S.; Lam, K.P.; Bazylinski, D.A.; Lins, U.; Hitchcock, A.P. Examining the chemistry and magnetism of magnetotactic bacterium Candidatus Magnetovibrio blakemorei strain MV-1 using scanning transmission X-ray microscopy. Chem. Geol. 2012, 300-301, 14-23. [CrossRef]

126. Firlar, E.; Ouy, M.; Bogdanowicz, A.; Covnot, L.; Song, B.; Nadkarni, Y.; Shahbazian-Yassar, R.; Shokuhfar, T. Investigation of the magnetosome biomineralization in magnetotactic bacteria using graphene liquid cell—Transmission electron microscopy. Nanoscale 2019, 11, 698-705. [CrossRef]

127. Bogachev, Y.V.; Chernenco, J.S.; Gareev, K.G.; Kononova, I.E.; Matyushkin, L.B.; Moshnikov, V.A.; Nalimova, S.S. The study of aggregation processes in colloidal solutions of magnetite-silica nanoparticles by NMR Relaxometry, AFM, and UV-visspectroscopy. Appl. Magn. Reson. 2014, 45, 329-337. [CrossRef]

128. Yamamoto, D.; Taoka, A.; Uchihashi, T.; Sasaki, H.; Watanabe, H.; Ando, T.; Fukumori, Y. Visualization and structural analysis of the bacterial magnetic organelle magnetosome using atomic force microscopy. Proc. Natl. Acad. Sci. USA 2010, 107, $9382-9387$. [CrossRef]

129. Grouzdev, D.S.; Dziuba, M.V.; Kurek, D.V.; Ovchinnikov, A.I.; Zhigalova, N.A.; Kuznetsov, B.B.; Skryabin, K.G. Optimized method for preparation of IgG-binding bacterial magnetic nanoparticles. PLoS ONE 2014, 9, e109914. [CrossRef]

130. Kornig, A.; Hartmann, M.A.; Teichert, C.; Fratzl, P.; Faivre, D. Magnetic force imaging of a chain of biogenic magnetite and Monte Carlo analysis of tip-particle interaction. J. Phys. D Appl. Phys. 2014, 47, 235403. [CrossRef] 
131. Marcuello, C.; Chambel, L.; Rodrigues, M.S.; Ferreira, L.P.; Cruz, M.M. Magnetotactic bacteria: Magnetism beyond magnetosomes. IEEE Trans. Nanobioscience 2018, 17, 555-559. [CrossRef] [PubMed]

132. Józefczak, A.; Leszczyński, B.; Skumiel, A.; Hornowski, T. A comparison between acoustic properties and heat effects in biogenic (magnetosomes) and abiotic magnetite nanoparticles suspensions. J. Magn. Magn. Mater. 2016, 407, 92-100. [CrossRef]

133. Józefczak, A.; Molčan, M.; Rozynek, Z.; Hornowskia, T.; Skumiel, A.; Timko, M.; Tóthová, J.; Kopčanský, P.; Leszczyński, B. Properties of magnetosome suspension under the influence of magnetic field. Acta Phys. Pol. A 2015, 127, 629-631. [CrossRef]

134. Kiani, B.; Faivre, D.; Klumpp, S. Elastic properties of magnetosome chains. New J. Phys. 2015, 17, 043007. [CrossRef]

135. Klumpp, S.; Kiani, B.; Vach, P.; Faivre, D. Navigation with magnetic nanoparticles: Magnetotactic bacteria and magnetic microrobots. Phys. Scr. 2015, T165, 014044. [CrossRef]

136. Lefèvre, C.T.; Pósfai, M.; Abreu, F.; Lins, U.; Frankel, R.B.; Bazylinski, D.A. Morphological features of elongated-anisotropic magnetosome crystals in magnetotactic bacteria of the Nitrospirae phylum and the Deltaproteobacteria class. Earth Planet. Sci. Lett. 2011, 312, 194-200. [CrossRef]

137. Moisescu, C.; Ardelean, I.I.; Benning, L.G. The effect and role of environmental conditions on magnetosome synthesis. Front. Microbiol. 2014, 5, 49. [CrossRef] [PubMed]

138. Wen, T.; Zhang, Y.; Geng, Y.; Liu, J.; Basit, A.; Tian, J.; Li, Y.; Li, J.; Ju, J.; Jiang, W. Epsilon-Fe ${ }_{2} \mathrm{O}_{3}$ is a novel intermediate for magnetite biosynthesis in magnetotactic bacteria. Biomater. Res. 2019, 23, 13. [CrossRef]

139. Prozorov, T.; Perez-Gonzalez, T.; Valverde-Tercedor, C.; Jimenez-Lopez, C.; Yebra-Rodriguez, A.; Körnig, A.; Faivre, D.; Mallapragada, S.K.; Howse, P.A.; Bazylinski, D.A.; et al. Manganese incorporation into the magnetosome magnetite: Magnetic signature of doping. Eur. J. Mineral. 2014, 26, 457-471. [CrossRef]

140. Grunberg, K.; Müller, E.-C.; Otto, A.; Reszka, R.; Linder, D.; Kube, M.; Reinhardt, R.; Schüler, D. Biochemical and proteomic analysis of the magnetosome membrane in magnetospirillum gryphiswaldense. Appl. Environ. Microbiol. 2004, 70, 1040-1050. [CrossRef]

141. Lang, C.; Schüler, D. Expression of green fluorescent protein fused to magnetosome proteins in microaerophilic magnetotactic bacteria. Appl. Environ. Microbiol. 2008, 74, 4944-4953. [CrossRef] [PubMed]

142. Curcio, A.; de Walle, A.V.; Serrano, A.; Preveral, S.; Péchoux, C.; Pignol, D.; Menguy, N.; Lefèvre, C.T.; Espinosa, A.; Wilhelm, C. Transformation cycle of magnetosomes in human stem cells: From degradation to biosynthesis of magnetic nanoparticles anew. ACS Nano 2020, 14, 1406-1417. [CrossRef]

143. Cypriano, J.; Bahri, M.; Dembelé, K.; Baaziz, W.; Leão, P.; Bazylinski, D.A.; Abreu, F.; Ersen, O.; Farina, M.; Werckmann, J. Insight on thermal stability of magnetite magnetosomes: Implications for the fossil record and biotechnology. Sci. Rep. 2020, 10, 6706. [CrossRef]

144. Riese, C.N.; Uebe, R.; Rosenfeldt, S.; Schenk, A.S.; Jérôme, V.; Freitag, R.; Schüler, D. An automated oxystat fermentation regime for microoxic cultivation of Magnetospirillum gryphiswaldense. Microb. Cell Fact. 2020, 19, 206. [CrossRef] [PubMed]

145. Matsunaga, T.; Kamiya, S. Use of magnetic particles isolated from magnetotactic bacteria for enzyme immobilization. Appl. Microbiol. Biotechnol. 1987, 26, 328-332. [CrossRef]

146. Alphandéry, E.; Chebbi, I.; Guyot, F.; Durand-Dubief, M. Use of bacterial magnetosomes in the magnetic hyperthermia treatment of tumours: A review. Int. J. Hyperth. 2013, 29, 801-809. [CrossRef] [PubMed]

147. Kirshvink, J.L. Paleomagnetic evidence for fossil biogenic magnetite in western Crete. Earth Planet. Sci. Lett. 1982, 59, 388-392. [CrossRef]

148. Yamazaki, T.; Fu, W.; Shimono, T.; Usui, Y. Unmixing biogenic and terrigenous magnetic mineral components in red clay of the Pacific Ocean using principal component analyses of first-order reversal curve diagrams and paleoenvironmental implications. Earth Planets Space 2020, 72, 120. [CrossRef]

149. Petersen, N.; von Dobeneck, T.; Vali, H. Fossil bacterial magnetite in deep-sea sediments from the South Atlantic Ocean. Nature 1986, 320, 611-615. [CrossRef]

150. Vali, H.; von Dobeneck, T.; Amarantidis, G.; Förster, O.; Morteani, G.; Bachmann, L.; Petersen, N. Biogenic and lithogenic magnetic minerals in Atlantic and Pacific deep sea sediments and their paleomagnetic significance. Geol. Rundsch. 1989, 78, 753-764. [CrossRef]

151. Yamazaki, T.; Shimono, T. Abundant bacterial magnetite occurrence in oxic red clay. Geology 2013, 41, 1191-1194. [CrossRef]

152. Chang, L.; Vasiliev, I.; van Baak, C.; Krijgsman, W.; Dekkers, M.J.; Roberts, A.P.; Fitz Gerald, J.D.; van Hoesel, A.; Winklhofer, M. Identification and environmental interpretation of diagenetic and biogenic greigite in sediments: A lesson from the Messinian Black Sea. Geochem. Geophys. Geosyst. 2014, 15, 3612-3627. [CrossRef]

153. Kurz, J.; Simon, K.; Heim, C.; Reitner, J.; Queric, N.V.; Volker, T. Trace element and biomarker signatures in iron-precipitating microbial mats from the tunnel of Äspö (Sweden). In Advances in Stromatolite Geobiology, Lecture Notes in Earth Sciences; Reitner, J., Quéric, N.-V., Arp, G., Eds.; Springer: Berlin, Germany, 2011; Volume 131, pp. 221-231. [CrossRef]

154. Reinholdsson, M.; Snowball, I. Magnetic quantification of Fe and S bound as magnetosomal greigite in laminated sapropels in deeper basins of the Baltic Sea. Biogeosciences Discuss. 2014, 11, 729-752. [CrossRef]

155. Stolz, J.F.; Chang, S.-B.R.; Kirschvink, J.L. Biogenic magnetite in stromatolites. I. Occurrence in modern sedimentary environments. Precambrian Res. 1989, 43, 295-304. [CrossRef] 
156. Koziaeva, V.V.; Alekseeva, L.M.; Uzun, M.M.; Leão, P.; Sukhacheva, M.V.; Patutina, E.O.; Kolganova, T.V.; Grouzdev, D.S. Biodiversity of magnetotactic bacteria in the freshwater lake Beloe Bordukovskoe, Russia. Microbiology 2020, 89, 348-358. [CrossRef]

157. Petersen, N.; Weiss, D.G.; Vali, H. Magnetic bacteria in lake sediments. In Geomagnetism and Palaeomagnetism; Lowes, F.J., Collinson, D.W., Parry, J.H., Runcorn, S.K., Tozer, D.C., Soward, A., Eds.; Kluwer Academic Publishers: Dordrecht, The Netherlands, 1989; pp. 231-241. [CrossRef]

158. Yamazaki, T. Reductive dissolution of biogenic magnetite. Earth Planets Space 2020, 72, 150. [CrossRef]

159. Blattmann, T.M.; Lesniak, B.; García-Rubio, I.; Charilaou, M.; Wessels, M.; Eglinton, T.I.; Gehring, A.U. Ferromagnetic resonance of magnetite biominerals traces redox changes. Earth Planet. Sci. Lett. 2020, 545, 116400. [CrossRef]

160. Egli, R. Characterization of individual rock magnetic components by analysis of remanence curves. 3 . Bacterial magnetite and natural processes in lakes. Phys. Chem. Earth 2004, 29, 869-884. [CrossRef]

161. Yamazaki, T.; Kawahata, H. Organic carbon flux controls the morphology of magnetofossils in marine sediments. Geology 1998, 26, 1064-1066. [CrossRef]

162. Kopp, R.E.; Schumann, D.; Raub, T.D.; Powars, D.S.; Godfrey, L.V.; Swanson-Hysell, N.L.; Maloof, A.C.; Vali, H. An Appalachian Amazon? Magnetofossil evidence for the development of a tropical river-like system in the mid-Atlantic United States during the Paleocene-Eocene thermal maximum. Paleoceanography 2009, 24, PA4211. [CrossRef]

163. Chang, S.-B.R.; Kirschvink, J.L. Biogenic magnetite as a primary remanence carrier in limestone deposits. Phys. Earth Planet. Inter. 1987, 46, 289-303. [CrossRef]

164. Vali, H.; Kirschvink, J.L. Magnetofossil dissolution in a palaeomagnetically unstable deep-sea sediment. Nature 1989, 339, $203-206$. [CrossRef]

165. Weiss, B.P.; Kim, S.S.; Kirschvink, J.L.; Kopp, R.E.; Sankaran, M.; Kobayashi, A.; Komeili, A. Magnetic tests for magnetosome chains in Martian meteorite ALH84001. Proc. Natl. Acad. Sci. USA 2004, 101, 8281-8284. [CrossRef] [PubMed]

166. Gandia, D.; Gandarias, L.; Marcano, L.; Orue, I.; Gil-Cartón, D.; Alonso, J.; García-Arribas, A.; Muela, A.; Fdez-Gubieda, M.L. Elucidating the role of shape anisotropy in faceted magnetic nanoparticles using biogenic magnetosomes as a model. Nanoscale 2020, 12, 16081-16090. [CrossRef] [PubMed]

167. Kopp, R.E.; Raub, T.D.; Schumann, D.; Vali, H.; Smirnov, A.V.; Kirschvink, J.L. Magnetofossil spike during the Paleocene-Eocene thermal maximum: Ferromagnetic resonance, rock magnetic, and electron microscopy evidence from Ancora, New Jersey, United States. Paleoceanography 2007, 22, PA4103. [CrossRef]

168. Kharitonskii, P.; Kamzin, A.; Gareev, K.; Valiullin, A.; Vezo, O.; Sergienko, E.; Korolev, D.; Kosterov, A.; Lebedev, S.; Gurylev, A.; et al. Magnetic granulometry and Mössbauer spectroscopy of $\mathrm{Fe}_{\mathrm{m}} \mathrm{O}_{\mathrm{n}}-\mathrm{SiO}_{2}$ colloidal nanoparticles. J. Magn. Magn. Mater. 2018, 461, 30-36. [CrossRef]

169. Kharitonskii, P.; Kirillova, S.; Gareev, K.; Kamzin, A.; Gurylev, A.; Kosterov, A.; Sergienko, E.; Valiullin, A.; Shevchenko, E. Magnetic granulometry and Mössbauer spectroscopy of synthetic $\mathrm{Fe}_{\mathrm{m}} \mathrm{O}_{\mathrm{n}}-\mathrm{TiO}_{2}$ composites. IEEE Trans. Magn. 2020, 56, 7200209. [CrossRef]

170. Kirschvink, J.L.; Chang, S.-B.R. Ultrafine-grained magnetite in deep-sea sediments: Possible bacterial magnetofossils. Geology 1984, 12, 559-562. [CrossRef]

171. Chang, S.-B.R.; Stolz, J.F.; Kirschvink, J.L.; Awramik, S.M. Biogenic magnetite in stromatolites. II. Occurrence in ancient sedimentary environments. Precambrian Res. 1989, 43, 305-315. [CrossRef]

172. Pan, Y.; Lin, W.; Tian, L.; Zhu, R.; Petersen, N. Combined approaches for characterization of an uncultivated magnetotactic coccus from Lake Miyun near Beijing. Geomicrobiol. J. 2009, 26, 313-320. [CrossRef]

173. Chang, S.-B.R.; Kirschvink, J.L. Magnetofossils, the magnetization of sediments, and the evolution of magnetite biomineralization. Annu. Rev. Earth Planet. Sci. 1989, 17, 169-195. [CrossRef]

174. Zhu, X.; Hitchcock, A.P.; Le Nagard, L.; Bazylinski, D.A.; Morillo, V.; Abreu, F.; Leão, P.; Lins, U. X-ray absorption spectroscopy and magnetism of synthetic greigite and greigite magnetosomes in magnetotactic bacteria. Geomicrobiol. J. 2018, 35, 215-226. [CrossRef]

175. Reinholdsson, M.; Snowball, I.; Zillén, L.; Lenz, C.; Conley, D.J. Magnetic enhancement of Baltic Sea sapropels by greigite magnetofossils. Earth Planet. Sci. Lett. 2013, 366, 137-150. [CrossRef]

176. Yan, L.; Yue, X.; Zhang, S.; Chen, P.; Xu, Z.; Li, Y.; Li, H. Biocompatibility evaluation of magnetosomes formed by Acidithiobacillus ferrooxidans. Mater. Sci. Eng. C 2012, 32, 1802-1807. [CrossRef] [PubMed]

177. Cypriano, J.; Werckmann, J.; Vargas, G.; dos Santos, A.L.; Silva, K.T.; Leão, P.; Almeida, F.P.; Bazylinski, D.A.; Farina, M.; Lins, U.; et al. Uptake and persistence of bacterial magnetite magnetosomes in a mammalian cell line: Implications for medical and biotechnological applications. PLoS ONE 2019, 14, e0215657. [CrossRef]

178. Jacob, J.J. Suthindhiran. K. Magnetotactic bacteria and magnetosomes—Scope and challenges. Mater. Sci. Eng. C 2016, 68, 919-928. [CrossRef] [PubMed]

179. Prabhu, N.N.; Kowshik, M. Magnetosomes: The bionanomagnets and its potential use in biomedical applications. J. Nanomed. Res. 2016, 3, 00057. [CrossRef]

180. Kuzajewska, D.; Wszołek, A.; Żwierełło, W.; Kirczuk, L.; Maruszewska, A. Magnetotactic bacteria and magnetosomes as smart drug delivery systems: A newweapon on the battlefield with cancer? Biology 2020, 9, 102. [CrossRef] 
181. Fdez-Gubieda, M.L.; Alonso, J.; García-Prieto, A.; García-Arribas, A.; Fernández Barquín, L.; Muela, A. Magnetotactic bacteria for cancer therapy. J. Appl. Phys. 2020, 128, 070902. [CrossRef]

182. Felfoul, O.; Mokrani, N.; Mohammadi, M.; Martel, S. Effect of the chain of magnetosomes embedded in magnetotactic bacteria and their motility on magnetic resonance imaging. In Proceedings of the 32nd Annual International Conference of the IEEE EMBS, Buenos Aires, Argentina, 31 August-4 September 2010. [CrossRef]

183. Herborn, C.U.; Papanikolaou, N.; Reszka, R.; Grünberg, K.; Schüler, D.; Debatin, J.F. Magnetosomes as biological model for iron binding: Relaxivity determination with MRI. Fortschr. Röntgenstr. 2003, 175, 830-834. [CrossRef]

184. Martel, S.; Mohammadi, M.; Felfoul, O.; Lu, Z.; Pouponneau, P. Flagellated magnetotactic bacteria as controlled mri-trackable propulsion and steering systems for medical nanorobots operating in the human microvasculature. Int. J. Robot. Res. 2009, 28, 571-582. [CrossRef] [PubMed]

185. Gandia, D.; Gandarias, L.; Rodrigo, I.; Robles-García, J.; Das, R.; Garaio, E.; García, J.A.; Phan, M.-H.; Srikanth, H.; Orue, I.; et al. Unlocking the potential of magnetotactic bacteria as magnetic hyperthermia agents. Small 2019, 15, 1902626. [CrossRef] [PubMed]

186. Chen, C.; Chen, L.; Wang, P.; Wu, L.-F.; Song, T. Steering of magnetotactic bacterial microrobots by focusing magnetic field for targeted pathogen killing. J. Magn. Magn. Mater. 2019, 479, 74-83. [CrossRef]

187. Boucher, M.; Geffroy, F.; Prévéral, S.; Bellanger, L.; Selingue, E.; Adryanczyk-Perrier, G.; Péan, M.; Lefévre, C.T.; Pignol, D.; Ginet, N.; et al. Genetically tailored magnetosomes used as MRI probe for molecular imaging of brain tumor. Biomaterials 2017, 121, 167-178. [CrossRef] [PubMed]

188. Xiang, Z.; Yang, X.; Xu, J.; Lai, W.; Wang, Z.; Hu, Z.; Tian, J.; Geng, L.; Fang, Q. Tumor detection using magnetosome nanoparticles functionalized with a newly screened EGFR/HER2 targeting peptide. Biomaterials 2017, 115, 53e64. [CrossRef]

189. Sun, Q.; Prato, F.S.; Goldhawk, D.E. Optimizing reporter gene expression for molecular magnetic resonance imaging. In Bioimaging; CRC Press: London, UK, 2020.

190. Yoshino, T.; Hirabe, H.; Takahashi, M.; Kuhara, M.; Takeyama, H.; Matsunaga, T. Magnetic cell separation using nano-sized bacterial magnetic particles with reconstructed magnetosome membrane. Biotechnol. Bioeng. 2008, 101, 470-477. [CrossRef]

191. Wacker, R.; Ceyhan, B.; Alhorn, P.; Schueler, D.; Lang, C.; Niemeyer, C.M. Magneto Immuno-PCR: A novel immunoassay based on biogenic magnetosome nanoparticles. Biochem. Biophys. Res. Commun. 2007, 357, 391-396. [CrossRef] [PubMed]

192. Wu, L.; Gao, B.; Zhang, F.; Sun, X.; Zhang, Y.; Li, Z. A novel electrochemical immunosensor based on magnetosomes for detection of staphylococcal enterotoxin B in milk. Talanta 2013, 106, 360-366. [CrossRef] [PubMed]

193. He, J.; Tian, J.; Xu, J.; Wang, K.; Li, J.; Gee, S.J.; Hammock, B.D.; Li, Q.X.; Xu, T. Strong and oriented conjugation of nanobodies onto magnetosomes for the development of a rapid immunomagnetic assay for the environmental detection of tetrabromobisphenol-A. Anal. Bioanal. Chem. 2018, 410, 6633-6642. [CrossRef]

194. Nakagawa, T.; Hashimoto, R.; Maruyama, K.; Tanaka, T.; Takeyama, H.; Matsunaga, T. Capture and release of DNA using aminosilane-modified bacterial magnetic particles for automated detection system of single nucleotide polymorphisms. Biotechnol. Bioeng. 2006, 94, 862-868. [CrossRef]

195. Yoza, B.; Matsumoto, M.; Matsunaga, T. DNA extraction using modified bacterial magnetic particles in the presence of amino silane compound. J. Biotechnol. 2002, 94, 217-224. [CrossRef]

196. Mickoleit, F.; Schüler, D. Generation of multifunctional magnetic nanoparticles with amplified catalytic activities by genetic expression of enzyme arrays on bacterial magnetosomes. Adv. Biosys. 2018, 2, 1700109. [CrossRef]

197. Mickoleit, F.; Schüler, D. Generation of nanomagnetic biocomposites by genetic engineering of bacterial magnetosomes. Bioinspired Biomim. Nanobiomater. 2019, 8, 86-98. [CrossRef]

198. Ren, E.; Lei, Z.; Wang, J.; Zhang, Y.; Liu, G. Magnetosome modification: From bio-nano engineering toward nanomedicine. Adv. Therap. 2018, 1, 1800080. [CrossRef]

199. Sun, J.; Li, Y.; Liang, X.-J.; Wang, P.C. Bacterial magnetosome: A novel biogenetic magnetic targeted drug carrier with potential multifunctions. J. Nanomater. 2011, 2011, 469031. [CrossRef] [PubMed]

200. Alphandéry, E. Applications of magnetosomes synthesized by magnetotactic bacteria in medicine. Front. Bioeng. Biotechnol. 2014, 2, 5. [CrossRef] [PubMed]

201. Liu, R.; Liu, J.; Tong, J.; Tang, T.; Kong, W.-C.; Wang, X.; Li, Y.; Tang, J. Heating effect and biocompatibility of bacterial magnetosomes as potential materials used in magnetic fluid hyperthermia. Prog. Nat. Sci. Mater. Int. 2012, 22, 31-39. [CrossRef]

202. Toropova, Y.G.; Golovkin, A.S.; Malashicheva, A.B.; Korolev, D.V.; Gorshkov, A.N.; Gareev, K.G.; Afonin, M.V.; Galagudza, M.M. In vitro toxicity of $\mathrm{Fe}_{\mathrm{m}} \mathrm{O}_{\mathrm{n}}, \mathrm{Fe}_{\mathrm{m}} \mathrm{O}_{\mathrm{n}}-\mathrm{SiO}_{2}$ composite, and $\mathrm{SiO}_{2}-\mathrm{Fe}_{\mathrm{m}} \mathrm{O}_{\mathrm{n}}$ core-shell magnetic nanoparticles. Int. J. Nanomed. 2017, 12, 593-603. [CrossRef]

203. Le Fèvre, R.; Durand-Dubief, M.; Chebbi, I.; Mandawala, C.; Lagroix, F.; Valet, J.-P.; Idbaih, A.; Adam, C.; Delattre, J.-Y.; Schmitt, C.; et al. Enhanced antitumor efficacy of biocompatible magnetosomes for the magnetic hyperthermia treatment of glioblastoma. Theranostics 2017, 7, 4618-4631. [CrossRef]

204. Wang, P.P.; Chen, C.; Chen, C.; Li, Y.; Pan, W.; Song, T. The interaction of bacterial magnetosomes and human liver cancer cells in vitro. J. Magn. Magn. Mater. 2017, 427, 105-110. [CrossRef]

205. Geng, Y.; Wang, J.; Wang, X.; Liu, J.; Zhang, Y.; Niu, W.; Basit, A.; Liu, W.; Jiang, W. Growth-inhibitory effects of anthracyclineloaded bacterial magnetosomes against hepatic cancer in vitro and in vivo. Nanomedicine 2019, 14, 1663-1680. [CrossRef] 
206. Wang, X.; Wang, J.; Geng, Y.; Wang, J.; Zhang, X.; Yang, S.; Jiang, W.; Liu, W. An enhanced anti-tumor effect of apoptin-cecropin B on human hepatoma cells by using bacterial magnetic particle gene delivery system. Biochem. Biophys. Res. Commun. 2018, 496, 719-725. [CrossRef] [PubMed]

207. Wang, J.; Geng, Y.; Zhang, Y.; Wang, X.; Liu, J.; Basit, A.; Miao, T.; Liu, W.; Jiang, W. Bacterial magnetosomes loaded with doxorubicin and transferrin improve targeted therapy of hepatocellular carcinoma. Nanotheranostics 2019, 3, 284-298. [CrossRef]

208. Macías-Martínez, B.I.; Cortés-Hernández, D.A.; Zugasti-Cruz, A.; Cruz-Ortíz, A.; Múzquiz-Ramos, E.M. Original. Heating ability and hemolysis test of magnetite nanoparticles obtained by a simple co-precipitation method. J. Appl. Res. Technol. 2016, 14, 239-244. [CrossRef]

209. Mannucci, S.; Tambalo, S.; Conti, G.; Ghin, L.; Milanese, A.; Carboncino, A.; Nicolato, E.; Marinozzi, M.R.; Benati, D.; Bassi, R.; et al. Magnetosomes extracted from magnetospirillum gryphiswaldense as theranostic agents in an experimental model of glioblastoma. Contrast Media Mol. Imaging 2018, 2018, 2198703. [CrossRef]

210. Briceño, S.; Hernandez, A.C.; Sojo, J.; Lascano, L.; Gonzalez, G. Degradation of magnetite nanoparticles in biomimetic media. J. Nanopart. Res. 2017, 19, 140. [CrossRef]

211. Chen, C.; Chen, L.; Wang, P.; Wu, L.-F.; Song, T. Magnetically-induced elimination of Staphylococcus aureus by magnetotactic bacteria under a swing magnetic field. Nanomed. Nanotechnol. Biol. Med. 2017, 13, 363-370. [CrossRef] [PubMed]

212. Cai, F.; Li, J.; Sun, J.; Ji, Y. Biosynthesis of gold nanoparticles by biosorption using Magnetospirillum gryphiswaldense MSR-1. Chem. Eng. J. 2011, 175, 70-75. [CrossRef]

213. Alphandéry, E.; Guyot, F.; Chebbi, I. Preparation of chains of magnetosomes, isolated from Magnetospirillum magneticum strain AMB-1 magnetotactic bacteria, yielding efficient treatment of tumors using magnetic hyperthermia. Int. J. Pharm. 2012, 434, 444-452. [CrossRef]

214. Alphandéry, E.; Idbaih, A.; Adame, C.; Delattre, J.-Y.; Schmitt, C.; Guyot, F.; Chebbi, I. Chains of magnetosomes with controlled endotoxin release and partial tumor occupation induce full destruction of intracranial U87-Luc glioma in mice under the application of an alternating magnetic field. J. Control. Release 2017, 262, 259-272. [CrossRef]

215. Alphandéry, E.; Idbaih, A.; Adam, C.; Delattre, J.-Y.; Schmitt, C.; Gazeau, F.; Guyot, F.; Chebbi, I. Biodegraded magnetosomes with reduced size and heating power maintain a persistent activity against intracranial U87-Luc mouse GBM tumors. J. Nanobiotechnol. 2019, 17, 126. [CrossRef] [PubMed]

216. Mathuriya, A.S. Magnetotactic bacteria for cancer therapy. Biotechnol. Lett. 2015, 37, 491-498. [CrossRef] [PubMed]

217. Felfoul, O.; Mohammadi, M.; Taherkhani, S.; De Lanauze, D.; Zhong Xu, Y.; Loghin, D.; Essa, S.; Jancik, S.; Houle, D.; Lafleur, M.; et al. Magneto-aerotactic bacteria deliver drug-containing nanoliposomes to tumour hypoxic regions. Nat. Nanotechnol. 2016, 11, 941-947. [CrossRef] [PubMed] 